\title{
Atmospheric nanoparticle observations in the low free troposphere during upward orographic flows at Izaña Mountain Observatory
}

\author{
S. Rodríguez ${ }^{1,2}$, Y. González ${ }^{1}$, E. Cuevas ${ }^{1}$, R. $\operatorname{Ramos}^{1}$, P. M. Romero ${ }^{1}$, J. Abreu-Afonso ${ }^{1,2,3}$, and A. Redondas ${ }^{1}$ \\ ${ }^{1}$ Izaña Atmospheric Research Centre, AEMET, Associated Unit to CSIC “Studies on Atmospheric Pollution”, La Marina 20, \\ Planta 6, E38071, Santa Cruz de Tenerife, Canary Islands, Spain \\ ${ }^{2}$ University of Huelva, Associated Unit to CSIC “Air Pollution”, Campus El Carmen, E21071, Huelva, Spain \\ ${ }^{3}$ Institute for Environmental Assessment and Water Research IDAEA, CSIC, Jordi Girona 18, E08034, Barcelona, Spain
}

Received: 26 February 2009 - Published in Atmos. Chem. Phys. Discuss.: 4 May 2009

Revised: 21 July 2009 - Accepted: 3 August 2009 - Published: 2 September 2009

\begin{abstract}
This study investigates the processes and conditions favouring the formation of nanoparticles (diameter $<10 \mathrm{~nm}$ ) which are frequently observed on high mountains reaching the low free troposphere. This was done through an analysis of a data set collected at Izaña Global Atmospheric Watch Observatory (Canary Islands; $2367 \mathrm{~m}$ above sea level). This high mountain supersite is located well above the stratocumulus layer characteristic of the subtropical oceanic tropospheres. At night, when the catabic flow regime is well established, free troposphere aerosols were measured. The development of orographic buoyant upward flows during daylight resulted in an increase of water vapour, $\mathrm{SO}_{2}$ and $\mathrm{NO}_{\mathrm{y}}$ concentrations. These ascending airflows perturbed the free troposphere and resulted in high concentrations of 3-10 nm particles $\left(\mathrm{N}_{3-10}\right)$ due to new particle formation. An analysis of the 5-min average time series allowed the identification of two main types of $\mathrm{N}_{3-10}$ event. In Type I events a linear relationship between $\mathrm{N}_{3-10}$ and $\mathrm{SO}_{2}$ was observed $\left(r^{2}\right.$ coefficients $0.70-0.95$ and a mean slope of $11 \mathrm{~cm}^{-3} \mathrm{ppt}^{-1}$ for 5-min averaged data; $\mathrm{SO}_{2}$ concentrations from tens to hundreds of $\mathrm{ppt}$ ). These particles seem to be formed during upward transport (probably within or after the outflows of clouds typically located below Izaña). During Type II events, no correlation between $\mathrm{SO}_{2}$ and $\mathrm{N}_{3-10}$ was observed and 3-10 nm particles were formed in-situ at noon and during the afternoon due to the condensation of vapours linked to photochemistry. New particle formation was observed almost every day owing
\end{abstract}

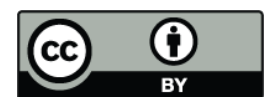

Correspondence to: S. Rodríguez (srodriguez@inm.es) to the favourable conditions associated with the entry of boundary layer air in the low free troposphere, even if $\mathrm{SO}_{2}$ concentrations are rather low at Izaña (tens to hundreds of ppt). The low surface area of pre-existing particles, low temperature and high radiation intensity clearly favoured the formation of nanoparticles. The low surface area of pre-existing particles in the upward flows is furthered by in-cloud particles scavenging in the stratocumulus layer typically located below Izaña. The higher temperature and the presence of coarse Saharan dust particles decrease the efficiency of the new particle formation mechanisms in summer. Thus, the " $\mathrm{N}_{3-10}$ versus $\mathrm{SO}_{2}$ " slope (for $r^{2}>0.7$ cases) was higher in autumn and winter $\left(\sim 15 \mathrm{~cm}^{-3} \mathrm{ppt}^{-1}\right.$ as average) than in summer $\left(2-8 \mathrm{~cm}^{-3} \mathrm{ppt}^{-1}\right)$. These field observations suggest that elevated mounts that reaches the free troposphere may act as source regions for new particles.

\section{Introduction}

New particle formation (NPF) by nucleation and subsequent growth processes has become a topic of great interest in atmospheric and environmental sciences. These particles are initially detected at sizes $\geq 3 \mathrm{~nm}$ and may grow until reaching a size within the range of $50 \mathrm{~nm}$ to $>100 \mathrm{~nm}$. In urban environments they may affect human health, whereas on global and regional scales, they may influence the climate by acting as cloud condensation nuclei and playing a role in the hydrological cycle and radiative balance.

A concerted effort is currently being made to understand the mechanism(s) resulting in nucleation and subsequent particle growth. Several theories have been proposed as

Published by Copernicus Publications on behalf of the European Geosciences Union. 
candidates for the initial cluster formation, such as "binary $\mathrm{H}_{2} \mathrm{O}-\mathrm{H}_{2} \mathrm{SO}_{4}$ nucleation" (Easter and Peters, 1994), "ternary $\mathrm{H}_{2} \mathrm{O}-\mathrm{H}_{2} \mathrm{SO}_{4}-\mathrm{NH}_{3}$ nucleation" (Eisele and McMurry, 1997), "nucleation of low vapour pressure organic compounds" (O'Dowd et al., 2002), "ion-induced nucleation" (Kim et al., 2002) and more recently "activation of existing neutral and/or ion clusters" (Kulmala et al., 2006).

Two steps are necessary in the NPF process (Kulmala et al., 2000): i) nucleation of an initial cluster (the nucleation process itself), and ii) activation of these clusters resulting in particle growth to a detectable diameter $(\geq 3 \mathrm{~nm})$. After a set of field measurement campaigns, Kulmala and co-workers (Kulmala et al., 2005; Kulmala and Tammet, 2007) observed that the clusters necessary for the initial steps seem to be always present in the atmosphere. They concluded that nucleation of sulphuric acid gas molecules play a key role in the formation of such stable clusters $(0.5-1.5 \mathrm{~nm}$ size; Kulmala et al., 2006; Kulmala and Kerminen, 2008). Thus, the socalled "NPF events" occur when clusters are activated and grow to detectable sizes $(\geq 3 \mathrm{~nm})$. It is believed that "nucleation" and "cluster and particle growth" may frequently be decoupled processes and that species involved in the nucleation step might not necessarily be the same as those involved in the cluster/particle growth (Kulmala et al., 2004). It is considered that sulphuric acid may also be involved in the initial steps of cluster and particle growth (Feidler et al., 2005). Moreover, there is an increasing amount of evidence pointing to the fact that condensation of organic vapours onto the cluster/particles may also result in growth processes. This includes organic compounds resulting from the oxidation of species linked to biogenic emissions, such as isoprene and terpenes (Marti et al., 1996; Allan et al., 2006; Laaksonen et al., 2008). Kulmala and Kerminen (2008) pointed out that a "high vapour source rate" (typically via active photochemistry and/or biogenic source) and a "low sink due to low surface area of pre-existing particles" are two crucial factors necessary for new particle formation and growth.

NPF has been observed in the continental boundary layer (Weber et al., 1997; Boy and Kulmala, 2002; Stanier et al., 2004; Fiedler et al., 2005; Rodríguez et al., 2005; Kulmala et al., 2006) and in the mid and upper free troposphere (Herman et al., 2003; Schröder et al., 2004; Kanawade and Tripathi, 2006; Benson et al., 2008). Moreover, it may also occur in the outflows of orographic clouds (Wiedelsohler et al., 1997) and in proximity to stratus, cirrus and marine cumulus (Hegg et al., 1991; Perry and Hobbs, 1994; Clarke et al., 1998; Lee et al., 2004). These investigations have shown that NPF is a process strongly dependent on environmental conditions. An example of this is that the occurrence of nanoparticles (diameter $<10 \mathrm{~nm}$ ) in the continental boundary layer is highly influenced by solar radiation, temperature, water vapour, relative humidity and the concentration of pre-existing particles and sulphuric acid and/or organic vapours (Weber et al., 1997; Boy and Kulmala, 2002; Stanier et al., 2004; Fiedler et al., 2005; Rodríguez et al., 2005; Kulmala et al., 2006).
NPF has also been observed on high mountains that reach the low free troposphere, such as Jungfraujoch (3580 m a.s.l., Switzerland), Monte Cimone (2165 m a.s.l., Italy), Mauna Loa (3400 ma.s.l., Hawaii), Khumbu (5079 m a.s.1., Nepal), Puy de Dôme (1465 m a.s.1.; France), Norikura (2770 m a.s.l.; Japan) and Lemmon (2790 m a.s.l., USA; Weber et al., 1996; Weber and McMurry, 1996; Weingartner et al., 1999; Van Dingenen et al., 2005; Shaw et al., 2007; Nishita et al., 2008; Venzac et al., 2007, 2008, 2009). Because of the difficulties in performing measurements at such elevated (and frequently remote) sites, many of the studies have been based on short campaigns and in many cases did not include measurements of trace gases and other relevant parameters. Owing to this, the conditions favouring the occurrence of nanoparticles in the boundary layer to free troposphere transition region have not been deeply investigated.

The aim of this study is to investigate the processes and conditions that favour the formation of 3-10 nm particles observed on such high mountains entering the low free troposphere. For this purpose a comprehensive data base, collected at Izaña Mountain Observatory (Tenerife, Canary Islands, Fig. 1) during 2007-2008, has been analysed. Understanding the formation of particles $<10 \mathrm{~nm}$ has become a crucial matter to understand the initial steps of the growth processes that may result in particles of $50->100 \mathrm{~nm}$ in size.

\section{Meteorology and topography}

Izaña Observatory $\left(16^{\circ} 29^{\prime} 58^{\prime \prime} \mathrm{W} ; 28^{\circ} 18^{\prime} 32^{\prime \prime} \mathrm{N}\right)$ is a Global Atmospheric Watch station located on Tenerife (Canary Islands; Fig. 1) at $2367 \mathrm{~m}$ a.s.l. As typically occurs in subtropical oceanic atmospheres adjacent to the west of continents, the low troposphere in this region is strongly stratified due to the synoptic scale subsidence conditions. Two air masses are well differentiated by the presence of a temperature inversion layer (TIL; Fig. 2): the marine boundary layer (MBL) and the free troposphere (FT). In the moist and cool MBL, the NNE trade wind blows. Because under the trade wind regime condensation level is usually lower than the inversion level, the top of the MBL (frequently located just below the TIL) is characterised by a layer of stratocumulus formed by condensation of water vapour onto the available pre-existing particles (Fig. 2a). The presence of this stratocumulus layer creates a quasi-continuous (throughout the year) foggy and rainy regimen at altitudes of between 800 and $2000 \mathrm{~m}$ a.s.l. on the island, which is locally known as "horizontal rain". In the FT, NW subsiding dry airflows dominate throughout the year except in summer, when they are frequently alternated with SE airflows laden with Saharan mineral dust particles (Chiapello et al., 1999). The altitude at which the TIL is located undergoes a marked seasonal evolution similar to that observed in the Azores (Fig. 2b; Kleissl et al., 2007). A view of the northern side of Tenerife above the stratocumulus clouds layer is shown in Fig. 3. 

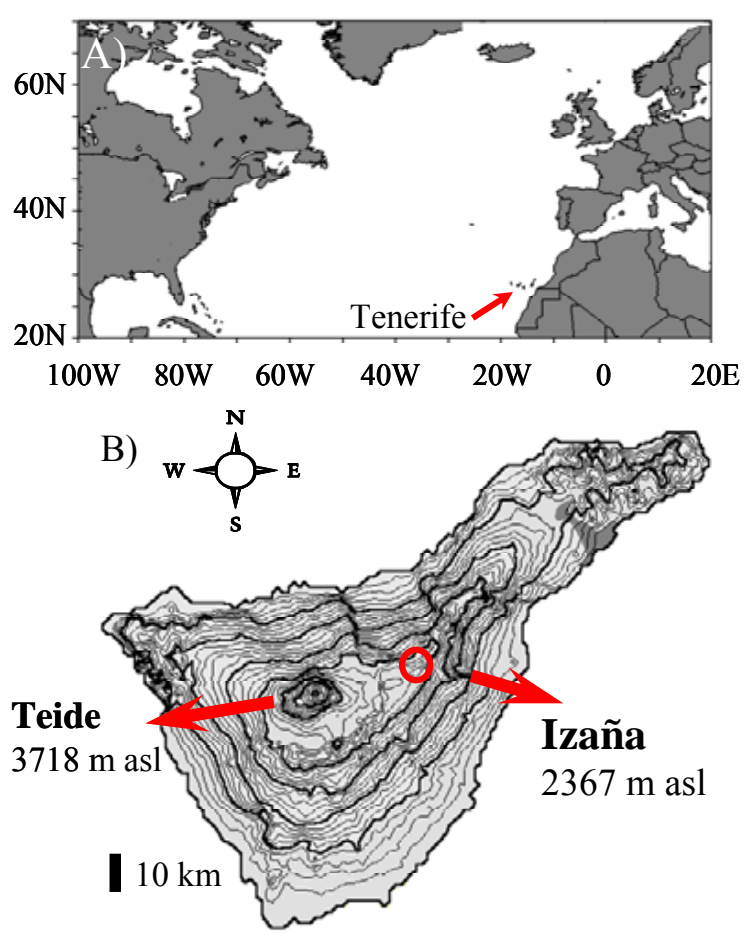

Fig. 1. Maps showing the location of Tenerife in the North Atlantic (A) and Izaña Observatory on Tenerife (B). Map B includes 100 and $500 \mathrm{~m}$ height lines, grey and black lines, respectively.

Tenerife has a central volcanic caldera (20002200 m a.s.l.; Fig. 1b) that serves as a base for the volcano Teide (3718 m a.s.l.; Fig. 1). A ridge, crossing SW to NE, divides the island into two main slopes: the northern and southern slopes. Tenerife is surrounded by a "ring" of forest of an endemic species of pine (Pinus canariensis Chr, Sm. ex DC) located between 600 and $2000 \mathrm{~m}$ a.s.l. owing to the water supply from the "horizontal rain" linked to the presence of the stratocumulus. Above 2000 ma.s.l., the terrain is arid and a local species of broom (Spartocytisus supranubius, local name "retama") is the predominant plant species. Urban areas on the island are mostly located below $600 \mathrm{~m}$ a.s.l.

\section{Measurements}

\subsection{Particles}

The main aerosol data set used in this study is the number concentration of particles with a diameter of 3-10 nm $\left(\mathrm{N}_{3-10}\right)$. This was measured from November 2006 to December 2007 using two Condensation Particle Counters (CPC): a CPC model 3025A (TSI ${ }^{\mathrm{TM}}$ ) to measure the number of particles $>3 \mathrm{~nm}\left(\mathrm{~N}_{3}\right)$, and a CPC model 3010 (TSITM) to measure the number of particles $>10 \mathrm{~nm}\left(\mathrm{~N}_{10}\right)$. $\mathrm{N}_{3-10}$ was determined as the difference between $\mathrm{N}_{3}$ and $\mathrm{N}_{10}$. The
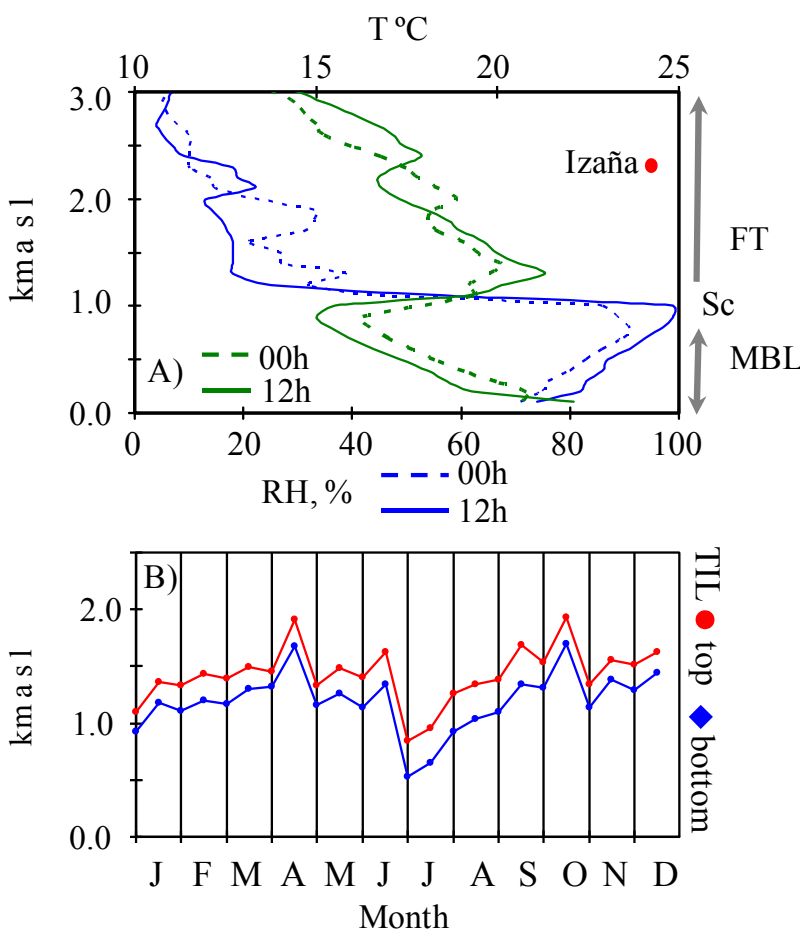

Fig. 2. (A) Vertical profile of temperature and relative humidity in Tenerife, highlighting the location of Izaña, the marine boundary layer (MBL), top and bottom of the temperature inversion layer, stratocumulus layer (Sc) and free troposphere (FT). (B) Monthly average values of the location of the top and bottom of the temperature inversion layer at 12:00 GMT and 00:00 GMT.

accuracy of the measurements was assessed comparing data from both CPCs. The readings from the instruments were almost identical at night owing to the extremely low concentrations of 3-10 nm particles in this period, whereas $\mathrm{N}_{3}$ and $\mathrm{N}_{10}$ differed during daylight due to new $3-10 \mathrm{~nm}$ particle formation (Fig. 4). Complementary aerosol measurements were performed. The number size distribution of particles with sizes between $14 \mathrm{~nm}$ and $20 \mu \mathrm{m}$ were measured with a Scanning Mobility Particle Sizer (TSI ${ }^{\mathrm{TM}}$ ) within the range 14-660 nm (an electrostatic classifier model 3080 connected to a CPC model 3025A; 24 June to 30 September, 2008) and an Aerodynamic Particle Sizer (APS model 3321 of TSITM; 2007-2008). Moreover, daily averaged PM $_{10}$ concentrations were determined during 2007-2008 by sampling on filter, whereas 1-min average $\mathrm{PM}_{10}$ concentrations were determined by converting the aerosol volume (calculated with the APS data) to aerosol mass concentrations using experimentally determined aerosol effective density. The airflow and zero of all aerosol instruments were checked several times per month and calibrations were performed if required. The Izaña programme for in-situ aerosol characterisation (www.izana.org) was audited by the World Calibration Centre for Aerosol Physics (WCCAP; Institute for Tropospheric Research, Leipzig) in November 2006. 


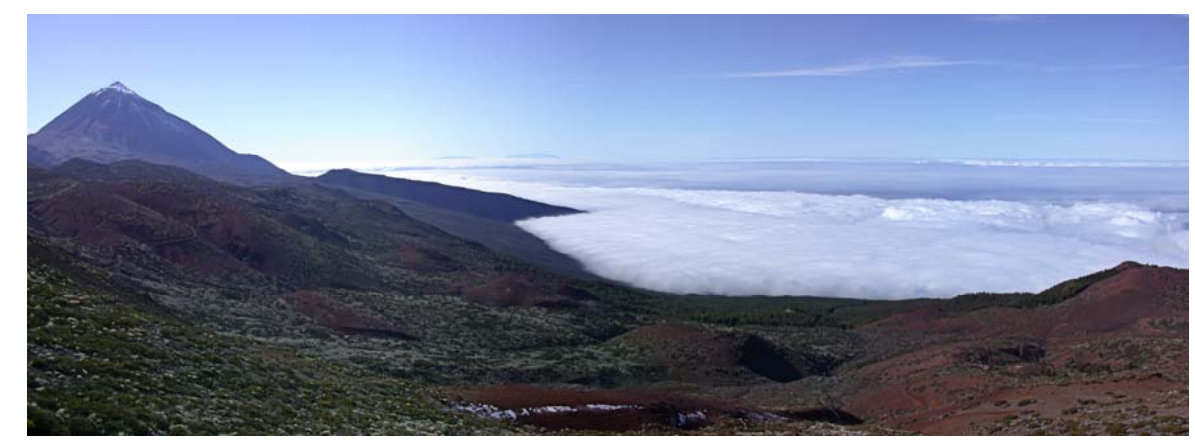

Fig. 3. Picture of the northern side of Tenerife (view from Izaña Observatory) showing how the terrain of the island emerges above the marine stratocumulus cloud layer and enters in the low free troposphere.
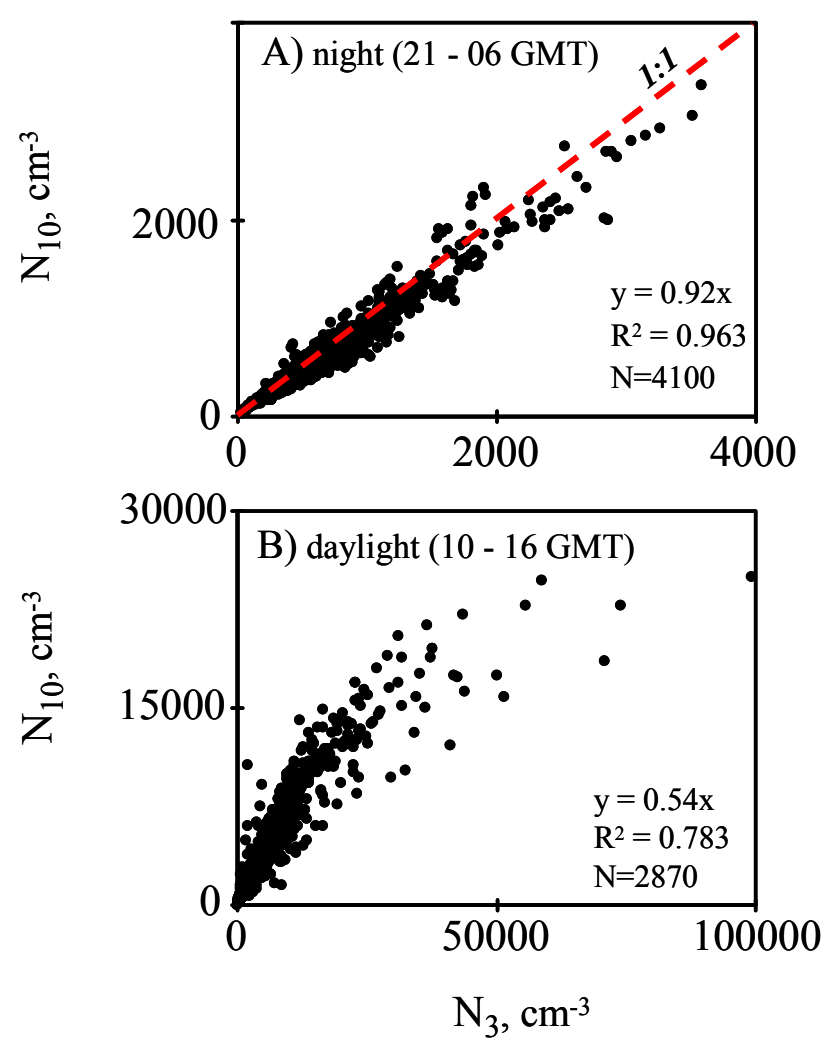

Fig. 4. $\mathrm{N}_{10}$ versus $\mathrm{N}_{3}$ concentrations recorded at Izaña during nocturnal (A) and diurnal (B) periods of 2007. N: number of hourly data used.

\subsection{Trace gases}

Trace gases measurements at Izaña started in November 2006. Concentrations of $\mathrm{SO}_{2}$ were monitored with a UV fluorescence analyser (Thermo ${ }^{\mathrm{TM}}$, model 43C-TL). NO was measured using the chemiluminescence reaction between $\mathrm{NO}$ and $\mathrm{O}_{3}$ as principle of measurement (Thermo ${ }^{\mathrm{TM}}$, model 42C-TL). Then, the concentrations of $\mathrm{NO}_{\mathrm{y}}$ compounds $\left[\mathrm{NO}_{\mathrm{y}}=\mathrm{NO}_{\mathrm{x}}\left(\mathrm{NO}+\mathrm{NO}_{2}\right)+\right.$ peroxyacetyl nitrate $(\mathrm{PAN})+$ alkyl nitrates+nitric acid $\left(\mathrm{HNO}_{3}\right)+$ nitrous acid $\left.(\mathrm{HONO})\right]$ were measured by passing the sample through a heated $\left(325^{\circ} \mathrm{C}\right)$ molybdenum converter, which reduces these species to and detects these species as NO. This technique does not properly quantify some components of $\mathrm{NO}_{\mathrm{y}}$ that were either reactive (e.g., $\mathrm{NO}_{3}$ ) or difficult to pass through the inlet (e.g., $\mathrm{HNO}_{3}$ ). These components usually accounts for $<15 \%$ of $\mathrm{NO}_{\mathrm{y}}$. All analysers are calibrated every 3 months, by performing a 5point calibration with certified gas concentrations, and all them showed high linearity in all the calibrations $\left(r^{2} \sim 0.999\right)$. A 15 -min zero was performed every $24 \mathrm{~h}$ in the $\mathrm{SO}_{2}$ analyser and every $6 \mathrm{~h}$ in the $\mathrm{NO}$ and $\mathrm{NO}_{\mathrm{y}}$ analyser. The instruments used have a detection limit of $60 \mathrm{ppt}$ for $\mathrm{SO}_{2}$ and $50 \mathrm{ppt}$ for $\mathrm{NO}$ and $\mathrm{NO}_{\mathrm{y}}$ for 5 -min averages. Because of the extremely clean air conditions in the free troposphere, the concentrations of these trace gases were very frequently below detection limit. In this study, only data recorded above detection limit have been used in the statistical analysis and for quantifying the relationship between trace gases and particle concentration (e.g. Table 2 and Figs. 9b, d, 11c, 14b and c). Some data recorded below detection limit have been included in several figures only for illustrating relative temporal variations, mostly night to daylight changes associated with upward flows (e.g. Figs. 5b, 9a, c, 10, 11a, b and 12).

\subsection{Radiation}

Solar Radiation was measured with World Meteorological Organisation Class I instruments. UV-B radiation (280$320 \mathrm{~nm}$ ) was measured with a Yankee Environmental System (YES) UVB-1 broadband radiometer. Global radiation (305$2800 \mathrm{~nm})$ and diffuse radiation $(305-2800 \mathrm{~nm})$ were monitored with Kipp \& Zonen CM21 radiometers. Direct radiation (200-4000 nm) was obtained with a Normal Incidence Pyrheliometer Kipp \& Zonen, CH-1 mounted on a Kipp \& Zonen 2AP Tracker. PAR (Photosynthetic Active Radiation), the integrated radiation within the $400-700 \mathrm{~nm}$ range was measured with a Kipp \& Zonen PAR-LITE radiometer. All radiation parameters are measured with 1-min resolution. 

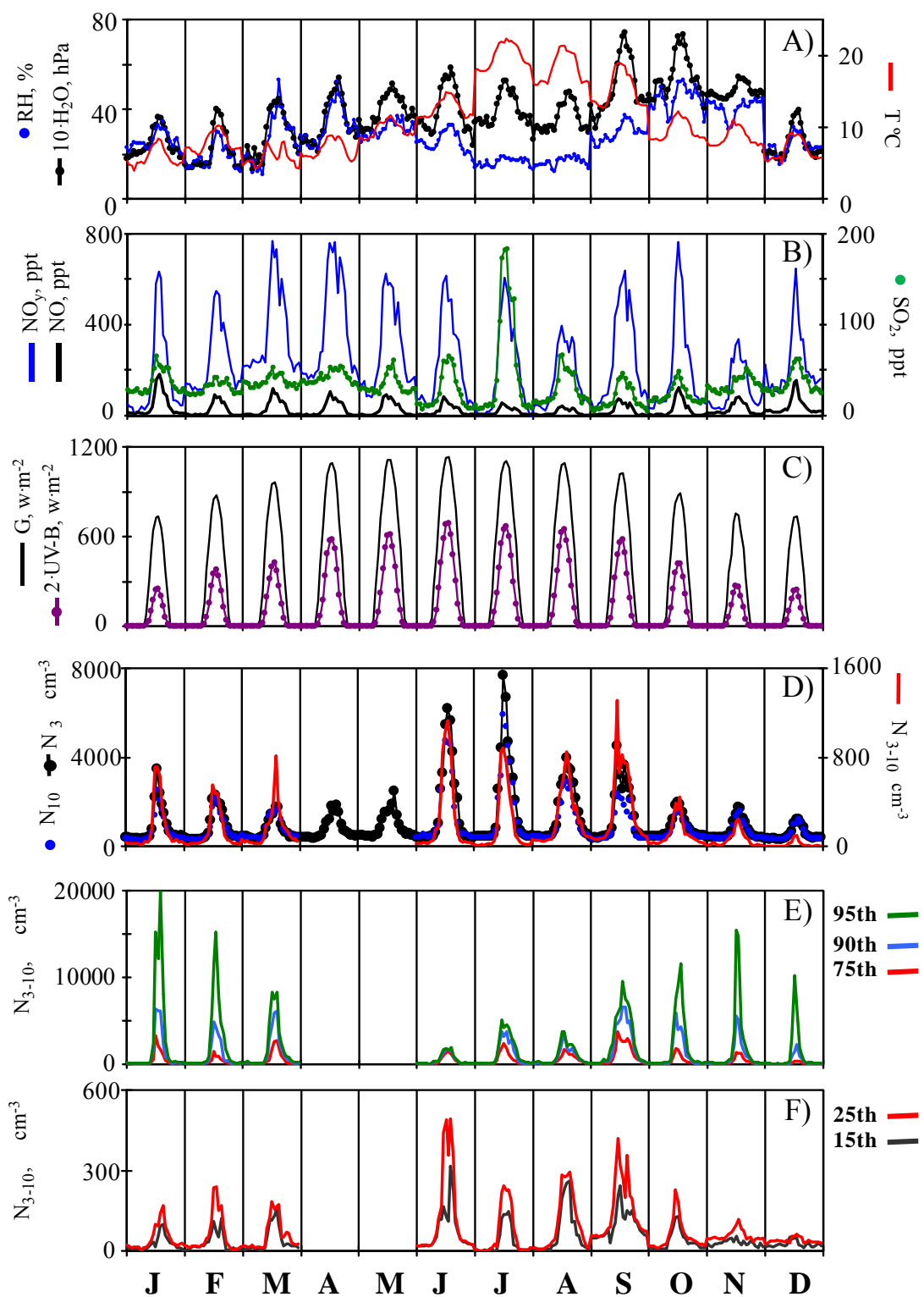

Fig. 5. Hourly median values and percentiles for each month of 2007 of: (A) relative humidity (RH), water vapour $\left(\mathrm{H}_{2} \mathrm{O}\right)$ and temperature $(T)$, (B) $\mathrm{SO}_{2}$ and $\mathrm{NO}_{\mathrm{y}}$ concentrations, (C) global (G) and UV-B radiation, (D) $\mathrm{N}_{10}, \mathrm{~N}_{3}$ and $\mathrm{N}_{3-10}$ concentrations, and (E) percentiles 70 th, 90th and 85th of $\mathrm{N}_{3-10}$, and (F) percentiles 15th and 25th of $\mathrm{N}_{3-10}$.

\subsection{Meteorology}

Meteorological parameters were measured using a Setra 470 instrument for pressure, a Rotronic for temperature and relative humidity, and a Thies Sonic anemometer for wind. Concentrations of water vapour were calculated with the Magnus equation. In this study, vertical profiles of temperature, humidity and wind speed obtained from meteorological radiosondes (Vaisala RS92+GPS) launched everyday (at 00:00 and 12:00 GMT) at Güimar site (on Tenerife, at $\sim 100 \mathrm{~m}$ a.s.l.) were also studied. These data allowed monitoring of the marine boundary layer depth.

\section{Results and discussion}

\subsection{Development of diurnal upward flows}

At Izaña, water vapour concentrations and relative humidity exhibit higher values during daylight than at night (Fig. 5a). This is caused by the occurrence of "upward transport of humid air during daylight" and "downward transport of dry free troposphere air at night". This diurnal upward flow is caused by two main processes:

- thermally driven vertical growth of the MBL depth caused by expansion of the MBL volume. Owing to 
Table 1. Statistics of the hourly particle number concentrations recorded at Izaña during the periods 17 November 2006 to 31 December 2007 (for $\mathrm{N}_{3}, \mathrm{~N}_{10}$ and $\mathrm{N}_{3-10}$ ) and 24 June 2008 to 1 October 2008 (for $\mathrm{N}_{13-660}$ and its subsets). Units: $\mathrm{cm}^{-3}$.

\begin{tabular}{lrrrrrrrrrr}
\hline & $\mathrm{N}_{3}$ & $\mathrm{~N}_{10}$ & $\mathrm{~N}_{3-10}$ & $\mathrm{~N}_{13-660}$ & $\mathrm{~N}_{13-20}$ & $\mathrm{~N}_{20-50}$ & $\mathrm{~N}_{50-100}$ & $\mathrm{~N}_{100-200}$ & $\mathrm{~N}_{200-500}$ & $\mathrm{~N}_{500-660}$ \\
\hline 00:00-05:00 GMT & & & & & & & & & & \\
mean & 479 & 445 & 38 & 362 & 7 & 126 & 102 & 103 & 23 & 0.5 \\
\% & & 92 & 8 & & 2 & 35 & 28 & 28 & 6 & $<0.1$ \\
25th & 316 & 293 & 3 & 166 & 2 & 39 & 73 & 44 & 8 & $<0.1$ \\
50th & 401 & 371 & 28 & 246 & 4 & 64 & 92 & 66 & 20 & 0.3 \\
75th & 526 & 490 & 64 & 352 & 9 & 94 & 119 & 97 & 32 & 0.6 \\
90th & 759 & 711 & 99 & 472 & 17 & 139 & 149 & 124 & 42 & 1.5 \\
11:00-16:00 GMT & & & & & & & & & & \\
mean & 4594 & 3179 & 1379 & 1498 & 201 & 848 & 292 & 122 & 35 & 0.6 \\
\% & & 70 & 30 & & 13 & 57 & 19 & 8 & 2 & $<0.1$ \\
25th & 942 & 828 & 78 & 404 & 20 & 157 & 130 & 76 & 22 & 0.0 \\
50th & 1891 & 1575 & 284 & 818 & 88 & 410 & 182 & 108 & 30 & 0.3 \\
75th & 5304 & 4040 & 1068 & 1841 & 263 & 1114 & 285 & 139 & 40 & 0.7 \\
90th & 11419 & 8428 & 3226 & 3335 & 555 & 2104 & 429 & 183 & 63 & 1.4 \\
\hline
\end{tabular}

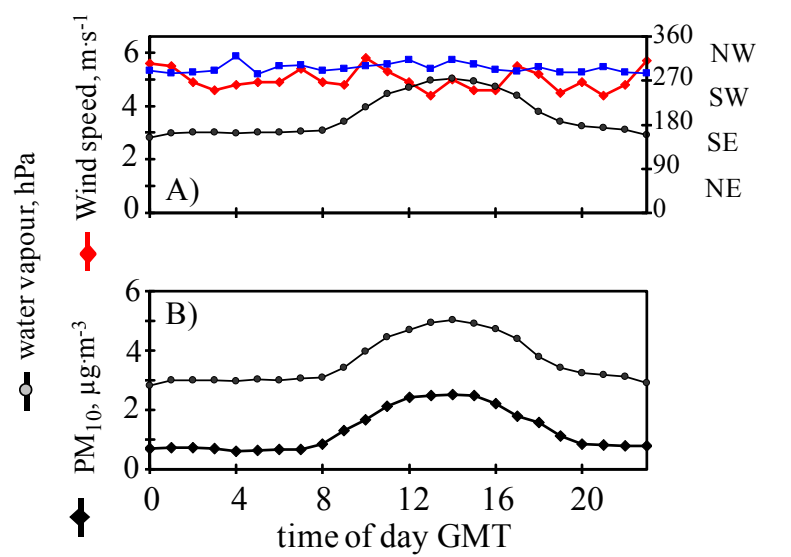

Fig. 6. Hourly values of the wind direction mode and of the averaged value of wind speed, water vapour (in both graphs) and particle mass $\mathrm{PM}_{10}$ concentrations at Izaña during 2007.

this, the top and bottom of the TIL are located at higher altitudes during daylight (1200 and $1700 \mathrm{~m}$ a.s.l., respectively) than at night (900 and $1300 \mathrm{~m}$ a.s.l., respectively; Fig. 2b). These vertical movements are also observed in the location of the stratocumulus layer (Font, 1956). The fact that the data plotted in Fig. 2 were obtained by sounding over the ocean indicates that this vertical growth of the MBL depth is not linked to vertical air motions over the island, but to a general behaviour over the ocean.

- buoyant airflows caused by the heating of the air located just above the terrain of the island. The fact that WNW winds predominate at Izaña (Fig. 6a) indicates that this upward transport of air is mostly linked to the development of buoyant flows on the northern slope of the island. This results in the lift of air masses that reach Tenerife from the north (due to synoptic winds). Mechanically forced upslope winds may occur under strong windy synoptic conditions, however, these may not account for the observed regular daily evolution of the water vapour and RH at Izaña. Upward winds linked to mechanically forced and buoyant airflows have also been observed at the Pico observatory in the Azores (Kleiss et al., 2007).

Because the occurrence of these upslope winds during daylight and downslope winds at night, the concentrations of $\mathrm{SO}_{2}, \mathrm{NO}$ and $\mathrm{NO}_{\mathrm{y}}$ exhibited clearly marked daily cycles similar to those of water vapour and RH (Fig. 5a and b). This $\mathrm{SO}_{2}$ transported to Izaña during daylight is most probably linked to anthropogenic emissions at low altitudes in the island (below the stratocumulus layer). In the case of NO, two possible sources may contribute: anthropogenic emissions at low altitude (as for $\mathrm{SO}_{2}$ ) and soil emissions (Kesik et al., 2005) in the vegetation "ring" surrounding the island. Oxidations products of $\mathrm{NO}$ accounts for the $\mathrm{NO}_{\mathrm{y}}$ also observed during daylight. It is important to highlight that, even if this upward transport occurs, trace gases concentrations are extremely low. The readings of the $\mathrm{SO}_{2}, \mathrm{NO}$ and $\mathrm{NO}_{\mathrm{y}}$ analysers typically showed concentrations of about 20,5 and $30 \mathrm{ppt}$ at night and of about 50, 80 and $600 \mathrm{ppt}$ during daylight, respectively (Fig. 5b). Many of instruments reading are frequently below the detection limit. The 5-min average $\mathrm{SO}_{2}, \mathrm{NO}$ and $\mathrm{NO}_{\mathrm{y}}$ concentrations were above detection limit (60 ppt for $\mathrm{SO}_{2}$ and $50 \mathrm{ppt}$ for $\mathrm{NO}$ and $\mathrm{NO}_{\mathrm{y}}$ ) only the 7,3 and $63 \%$ of time at night, and the 40,38 and $92 \%$ of time during daylight. The objective of the data plotted in 

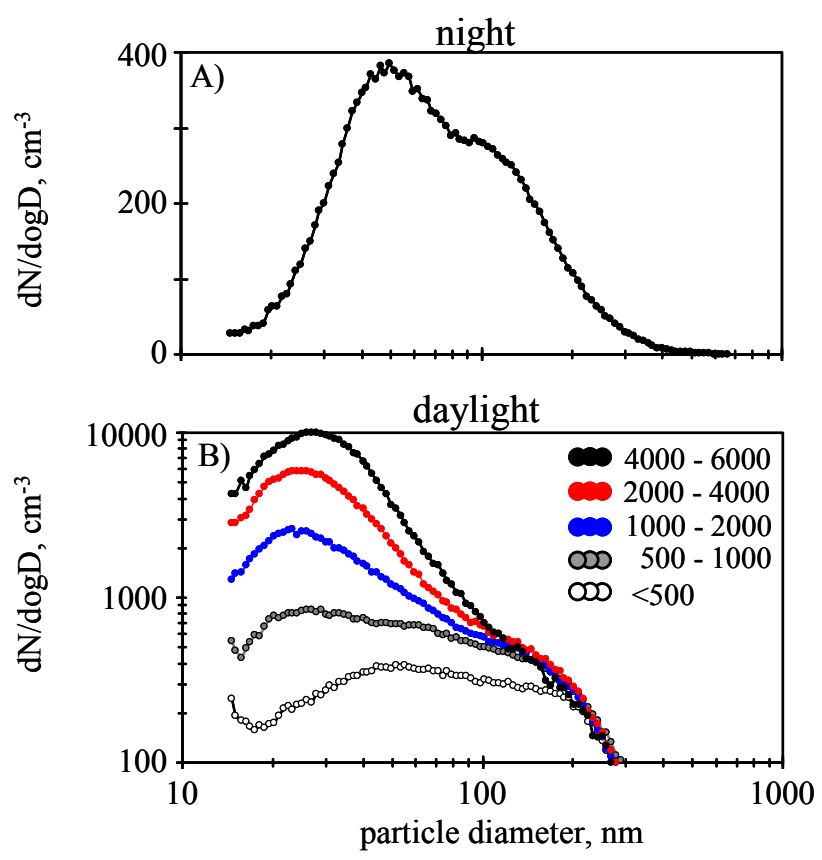

Fig. 7. Averaged $d N / d \log D$ size distribution recorded at Izaña: (A) at night (00:00-05:00 GMT), and (B) daylight episodes (10:0017:00 GMT) of $\mathrm{N}_{13-660}$ concentrations within the ranges $<500$, 500-1000, 2000-4000 and 4000-6000 $\mathrm{cm}^{-3}$.

Fig. 5b (obtained by averaging data collected both above and below detection limit) is simply to illustrate the strong nightto-daylight changes due to upward flows.

\subsection{Particle size distributions}

At Izaña, particle concentration exhibit daily cycles as those described for the trace gases. Observe that $\mathrm{N}_{3}$ and $\mathrm{N}_{3-10}$ typically show concentrations of about $480 \mathrm{~cm}^{-3}$ and $25 \mathrm{~cm}^{-3}$ at night and of about $4600 \mathrm{~cm}^{-3}$ and $600 \mathrm{~cm}^{-3}$ during daylight, respectively (Fig. 5d). The particle size distribution also exhibits a marked daily evolution (Fig. 7 and Table 1). During the night, a mean number concentration of $480 \mathrm{~cm}^{-3}$ was recorded and the $\mathrm{dN} / \mathrm{d} \log \mathrm{D}$ size distribution showed a $50 \mathrm{~nm}$ mode (Fig. 7a). Similar size distribution and number concentration were observed in the free troposphere at Mauna Loa (Weber and McMurry, 1996), Jungfraujoch (Weingartner et al., 1999), Puy de Dôme (Venzac et al., 2009) and Khumbu (Venzac et al., 2008). This was also observed by Raes et al. (1997) and Maring et al. (2000) at Izaña in July 1994 and July 1995, respectively. They observed that particles with a size of 50-60 $\mathrm{nm}$ were predominant during events of downward transport of air from the middle and upper troposphere and that these correlated well with ${ }^{7} \mathrm{Be}$. This supported the idea that this is an aged aerosol originally formed in the mid to upper troposphere.

The night-to-daylight increase in the particle number concentration is associated with a predominant increase in the concentrations of nucleation particles $(<20 \mathrm{~nm})$. Observe in Table 1 that the mean daylight-to-night concentrations ratio was equal to 37 for $\mathrm{N}_{3-10}, 29$ for $\mathrm{N}_{13-20}, 7$ for $\mathrm{N}_{20-50}, 3$ for $\mathrm{N}_{50-100}$ and $<2$ for the concentration of particles $>100 \mathrm{~nm}$ during the study period. The fact that the greatest increase in particle concentration is observed for particles $<20 \mathrm{~nm}$ indicates that the daily evolution of the particle number concentration is highly influenced by NPF during daylight. Because of this, the mode diameter of the $\mathrm{dN} / \mathrm{d} \log \mathrm{D}$ spectrum is lower during daylight $(20$ to $<50 \mathrm{~nm})$ than at night $(50 \mathrm{~nm})$. Moreover, the mode of the size distribution during daylight shifts towards lower diameters when the particle number concentration increases, in such a way that the $\mathrm{dN} / \mathrm{d} \log \mathrm{D}$ mode diameter exhibits values of about $53 \mathrm{~nm}, 27 \mathrm{~nm}$ and $23 \mathrm{~nm}$ when $\mathrm{N}_{13-660}$ exhibits values within the ranges $<500,500-$ 1000, 1000-6000 $\mathrm{cm}^{-3}$, respectively (Fig. 7b). This indicates that increases in particle number concentration are associated with increases in NPF rates.

The marked differences in nocturnal and diurnal particle number size distributions are easily observed in the examples shown in Fig. 8. In the unperturbed free troposphere at night, the Aitken mode is predominant. The development of buoyant flows during daylight results in upward transport of vapours and in NFP. Three different cases are shown. NPF followed by marked particle growth during daylight was observed on 25 July, 2008 (Fig. 8a). On 16 August, 2008 moderate particle growth occurred (Fig. 8b), whereas on $17^{\text {th }}$ July no particle growth was observed after the $13-20 \mathrm{~nm}$ event registered in the afternoon (Fig. 8c).

Daily cycles of the particle number concentration similar to those we observed at Izaña (prompted by NPF in the daylight upslope winds) were also observed at Jungfraujoch, Monte Cimone, Mauna Loa, Khumbu and Puy de Dôme (Weber et al., 1996; Weber and McMurry, 1996; Weingartner et al., 1999; Van Dingenen et al., 2005; Venzac et al., 2007).

\section{$4.3 \quad 3-10 \mathrm{~nm}$ particle events}

This and the following sections of this article focus on the investigation of the conditions that favour the formation of $3-10 \mathrm{~nm}$ particles necessary for the growth process resulting in NPF episodes. As described in the introduction, the formation of a 3-10 nm particle is understood as the result of two processes: nucleation of an initial cluster and activation of such cluster resulting in particle growth to detectable sizes $(\geq 3 \mathrm{~nm})$.

\subsubsection{Short time variations of $3-10 \mathrm{~nm}$ particles}

The processes that influence the short time variations of $\mathrm{N}_{3-10}$ were identified by performing a Principal Component Analysis (PCA) followed by varimax rotations using 5-min averaged data (e.g. as those plotted in Figs. 9 to 11). For the PCA, the data set was first normalised (by subtracting to each value the mean value of that variable in the whole data set, 


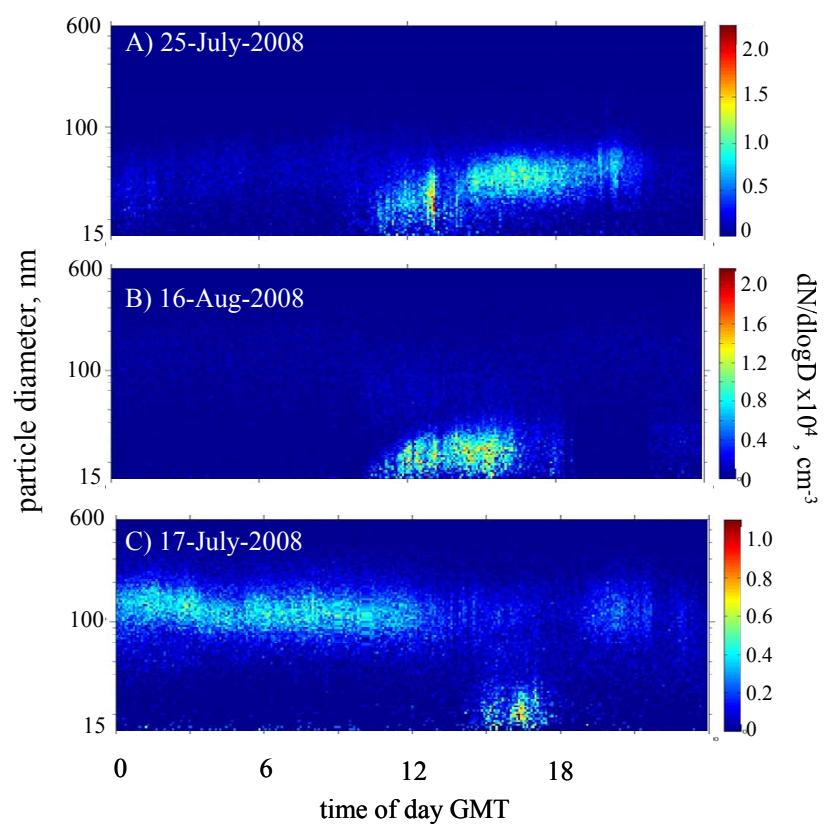

Fig. 8. 5-min values of the $d N / d \log D$ size distribution during three events.

and then dividing it by the standard deviation). A minimum value of 1.0 was set for the eigenvalues, whereas the maximum number of principal components allowed (PC) was set to 5. Usually, 3 to $4 \mathrm{PC}$ were obtained in each PCA. An initial PCA was performed with the whole data set $(\sim 1$ year). Subsequently, PCAs were performed month-by-month in order to study how the processes that influence on the 3-10 nm particle formation change along the year. Such PCAs were performed only on months when the number of days with data availability was $\geq 22$ days/month. In order to avoid the influence of the common daily patterns exhibited by some variables (e.g. those plotted in Fig. 5) the PCA was performed only during daylight (09:00-16:00 GMT). Owing to the PC obtained depends on the number and types of variables introduced in the PCA, a number of tests were performed by introducing different combinations of variables. Only $\mathrm{SO}_{2}, \mathrm{NO}$ and $\mathrm{NO}_{\mathrm{y}}$ data recorded above detection limit were used. Thus, about 25 PCAs were performed. For the sake of brevity, only two examples are shown (Table 2). In the PCA performed in the summer months three PCs were usually found (e.g. July 2007; Table 2):

- Principal Component 1 (PC-1) is positively correlated with $\mathrm{N}_{3-10}$ and direct (DI) radiation. This PC indicates that NPF by nucleation of photo-oxidized species may significantly contribute to $\mathrm{N}_{3-10}$. The negative association of $\mathrm{PM}_{10}$ and diffuse radiation (DF) with this $\mathrm{PC}$ indicates that high concentrations of pre-existing particles do not favour the occurrence of 3-10 $\mathrm{nm}$ particles. The negative correlation of temperature is attributed to the
Table 2. Factor loading of the Principal Components Analysis (followed by a varimax rotation) obtained with 5-min averaged data from 08:00 to 16:00 GMT in July and November 2007. Only trace gases concentrations above detection limit were used.

\begin{tabular}{lrrrrrr}
\hline & \multicolumn{3}{c}{ July 2007 } & \multicolumn{3}{c}{ November 2007 } \\
& PC1 & PC2 & PC3 & PC1 & PC2 & PC3 \\
\hline $\mathrm{N}_{3}-10$ & $\mathbf{0 . 5 1}$ & $\mathbf{0 . 5 0}$ & 0.06 & $\mathbf{0 . 7 6}$ & -0.06 & 0.22 \\
$\mathrm{PM}_{10}$ & $\mathbf{- 0 . 8 3}$ & 0.02 & -0.01 & -0.09 & $\mathbf{0 . 5 5}$ & $\mathbf{0 . 6 9}$ \\
$\mathrm{SO}_{2}$ & 0.18 & $\mathbf{0 . 6 7}$ & 0.05 & $\mathbf{0 . 8 9}$ & 0.07 & 0.24 \\
$\mathrm{NO}_{\mathrm{y}}$-NO & 0.18 & $\mathbf{0 . 5 7}$ & $\mathbf{0 . 7 5}$ & $\mathbf{0 . 8 6}$ & -0.01 & -0.27 \\
$\mathrm{NO}$ & -0.02 & 0.00 & $\mathbf{0 . 9 7}$ & $\mathbf{0 . 9 1}$ & 0.06 & -0.13 \\
$\mathrm{H} 2 \mathrm{O}$ & -0.04 & $\mathbf{0 . 6 0}$ & 0.16 & -0.07 & $\mathbf{- 0 . 4 0}$ & -0.10 \\
$\mathrm{DF}-\mathrm{RAD}$ & $\mathbf{- 0 . 9 3}$ & 0.03 & -0.04 & 0.14 & $\mathbf{0 . 8 2}$ & 0.22 \\
$\mathrm{DI}-\mathrm{RAD}$ & $\mathbf{0 . 8 8}$ & -0.02 & 0.07 & -0.03 & $-\mathbf{0 . 8 0}$ & 0.02 \\
$P$ & $\mathbf{0 . 6 8}$ & -0.39 & 0.05 & -0.04 & 0.38 & $\mathbf{0 . 8 3}$ \\
$T$ & $-\mathbf{0 . 7 6}$ & 0.48 & -0.06 & 0.16 & -0.36 & $\mathbf{0 . 7 1}$ \\
wind speed & $\mathbf{0 . 1 2}$ & $-\mathbf{0 . 8 3}$ & -0.01 & -0.24 & $\mathbf{0 . 7 9}$ & -0.12 \\
Var, $\%$ & 34 & 21 & 14 & 28 & 24 & 18 \\
\hline
\end{tabular}

fact that the condensation processes involved in the NPF are favoured under low temperature conditions, whereas the negative association of pressure is probably linked to the slight pressure drops during upward flows periods.

- Principal Component 2 (PC-2) is positively correlated with $\mathrm{N}_{3-10}$ and $\mathrm{SO}_{2}$. This PC represents NPF in relatively sulphur-rich (tens to hundreds of ppt) air masses. The correlation of the $\mathrm{NO}_{\mathrm{y}}-\mathrm{NO}$ difference with this $\mathrm{PC}$ evidences that these air masses are relatively enriched in aged nitrogenous compounds. The positive temperature and water vapour and negative wind speed associations indicate that buoyant upward flows are favoured by increases in temperature and decreases in synoptic wind speed.

- Principal Component 3 (PC-3) is positively correlated with $\mathrm{NO}$ and the $\mathrm{NO}_{\mathrm{y}}-\mathrm{NO}$ difference and represents the influence of the upward flows on the concentrations of nitrogenous species.

In the PCA performed in the winter months, it was observed that $\mathrm{N}_{3-10}$ and trace gases were associated with the same PC (e.g. November 2007; Table 2). The origin of the apparently lesser influence of $\mathrm{PM}_{10}$ and radiation on $\mathrm{N}_{3-10}$ is discussed below in detail. In the PCA performed with the whole data set, the most important association was that of $\mathrm{N}_{3-10}$ with $\mathrm{SO}_{2}$ and with $\mathrm{NO}_{\mathrm{y}}(\sim 1$ year $)$.

\subsubsection{Classification of 3-10 $\mathrm{nm}$ particle events}

A day-to-day analysis of the 5-min average time series was performed. Three types of event were found (Table 3):

- Type I. During these events, $\mathrm{N}_{3-10}$ concentrations higher than $500 \mathrm{~cm}^{-3}$ and correlations between $\mathrm{N}_{3-10}$ 

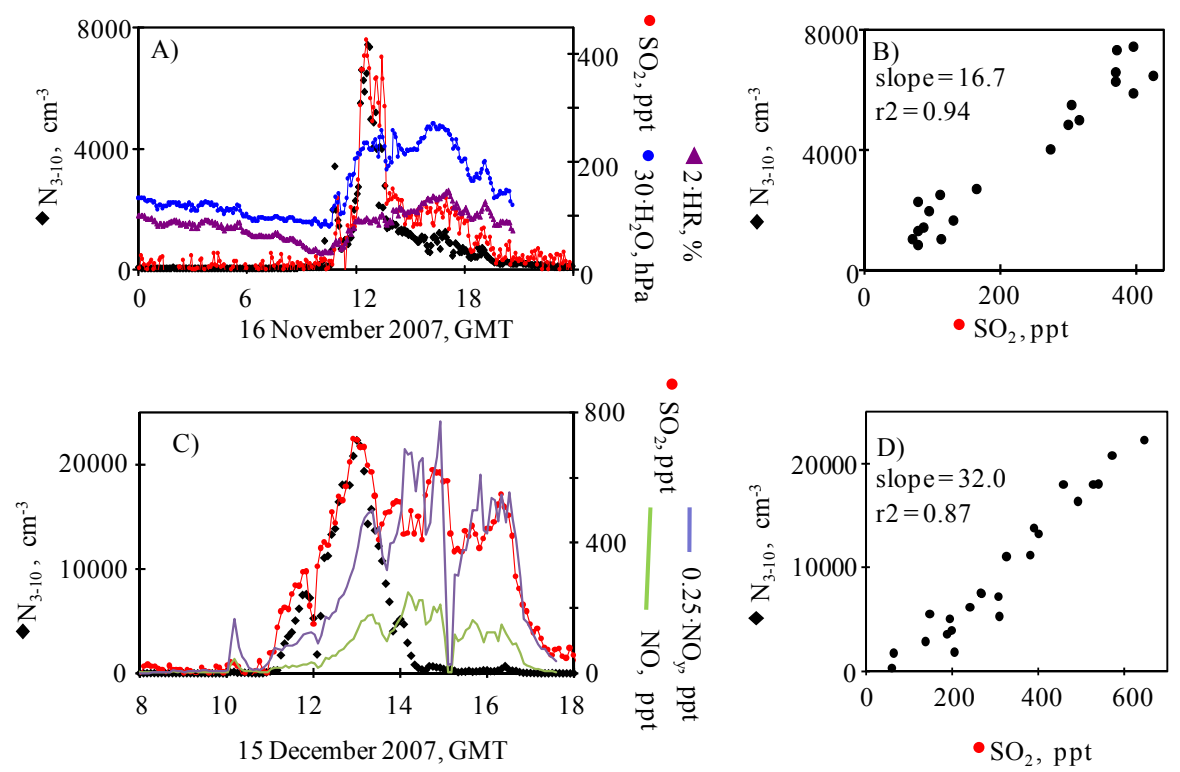

Fig. 9. 5-min averaged values of $\mathrm{N}_{3-10}, \mathrm{SO}_{2}$ and water vapour concentrations and relative humidity during two events Type I events (16 November 2007 and 15 December 2007).

Table 3. Data of $\mathrm{N}_{3-10}$ Types I, II and III events registered at Izaña from January to December 2007. Data availability in days. Number of events registered every month. Average start time, ending time and duration of the events for every month. Start and ending time for Type III events are not provided because they generally occurred during the whole daylight period.

\begin{tabular}{|c|c|c|c|c|c|c|c|c|c|c|}
\hline & $\begin{array}{r}\text { Data } \\
\text { Availability }\end{array}$ & $\begin{array}{r}\text { Number of } \\
\text { events }\end{array}$ & $\begin{array}{l}\text { Typ } \\
\text { start } \\
\text { time }\end{array}$ & $\begin{array}{l}\text { I } \\
\text { end } \\
\text { time }\end{array}$ & duration & $\begin{array}{r}\text { Number of } \\
\text { events }\end{array}$ & $\begin{array}{l}\text { Type } \\
\text { start } \\
\text { time }\end{array}$ & $\begin{array}{l}\text { II } \\
\text { end } \\
\text { time }\end{array}$ & duration & $\begin{array}{r}\text { Type III } \\
\text { Number of } \\
\text { events }\end{array}$ \\
\hline Jan & 29 & 3 & $10: 05$ & $12: 15$ & $02: 10$ & 19 & $12: 32$ & $15: 23$ & $02: 52$ & 16 \\
\hline Feb & 28 & 2 & 11:00 & $11: 45$ & $00: 45$ & 11 & $11: 37$ & $16: 08$ & $04: 31$ & 13 \\
\hline Mar & 22 & 2 & $10: 00$ & $13: 45$ & $03: 45$ & 7 & $11: 52$ & $15: 52$ & 04:00 & 9 \\
\hline Apr & 0 & & & & & & & & & \\
\hline May & 0 & & & & & & & & & \\
\hline Jun & 5 & 2 & $11: 15$ & $14: 40$ & $03: 25$ & 1 & 11:00 & $15: 00$ & 04:00 & 1 \\
\hline Jul & 31 & 12 & 09:40 & $13: 06$ & $03: 26$ & 6 & $12: 00$ & $14: 40$ & $02: 40$ & 10 \\
\hline Aug & 27 & 2 & $10: 00$ & $13: 00$ & 03:00 & 16 & $12: 34$ & $16: 53$ & 04:19 & 8 \\
\hline Sep & 28 & 7 & 09:20 & $12: 04$ & 02:44 & 16 & 11:08 & $16: 04$ & $04: 57$ & 6 \\
\hline Oct & 30 & 12 & 09:50 & $13: 24$ & $03: 34$ & 4 & 11:00 & $14: 30$ & $03: 30$ & 17 \\
\hline Nov & 29 & 10 & $10: 10$ & $12: 27$ & $02: 17$ & 6 & $12: 30$ & $15: 40$ & $03: 10$ & 15 \\
\hline Dec & 17 & 6 & $10: 45$ & $12: 22$ & $01: 37$ & 1 & $13: 00$ & $15: 00$ & 02:00 & 11 \\
\hline Total & 246 & 58 & & & & 87 & & & & 106 \\
\hline
\end{tabular}

and $\mathrm{SO}_{2}$ were observed. Most of these episodes occurred from 10:00 to 13:00 GMT (Table 3) and were caused by the arrival at Izaña of air from lower altitudes resulting in simultaneous increases in $\mathrm{N}_{3-10}$, $\mathrm{SO}_{2}$ and water vapour. Figure 9 shows some of these events occurred on 16 November 2007, from 10:50 to 12:40 GMT, (Fig. 9a) and on 15 December 2007, from 11:00 to 14:00 GMT (Fig. 9c). In this type of episode, the " $\mathrm{N}_{3-10}$ versus $\mathrm{SO}_{2}$ " concentrations exhibited a lin- ear relationship (see examples in Fig. 9c and d). The " $\mathrm{N}_{3-10}$ versus $\mathrm{SO}_{2}$ " slope of this first order equation ranged between 2 and $40 \mathrm{~cm}^{-3} \mathrm{ppt}^{-1}\left(r^{2}\right.$ coefficient was between 0.70 and 0.95 ) and showed an averaged value of $11 \mathrm{~cm}^{-3} \mathrm{ppt}^{-1}$ during the whole study period. This " $\mathrm{N}_{3-10}$ versus $\mathrm{SO}_{2}$ " slope is a measure of the NPF rates related to the $\mathrm{SO}_{2}$ to $\mathrm{H}_{2} \mathrm{SO}_{4}$ conversion, cluster activation and subsequent activation and growth to detectable sizes $(\geq 3 \mathrm{~nm}$ ). A total of 58 events (with an average 

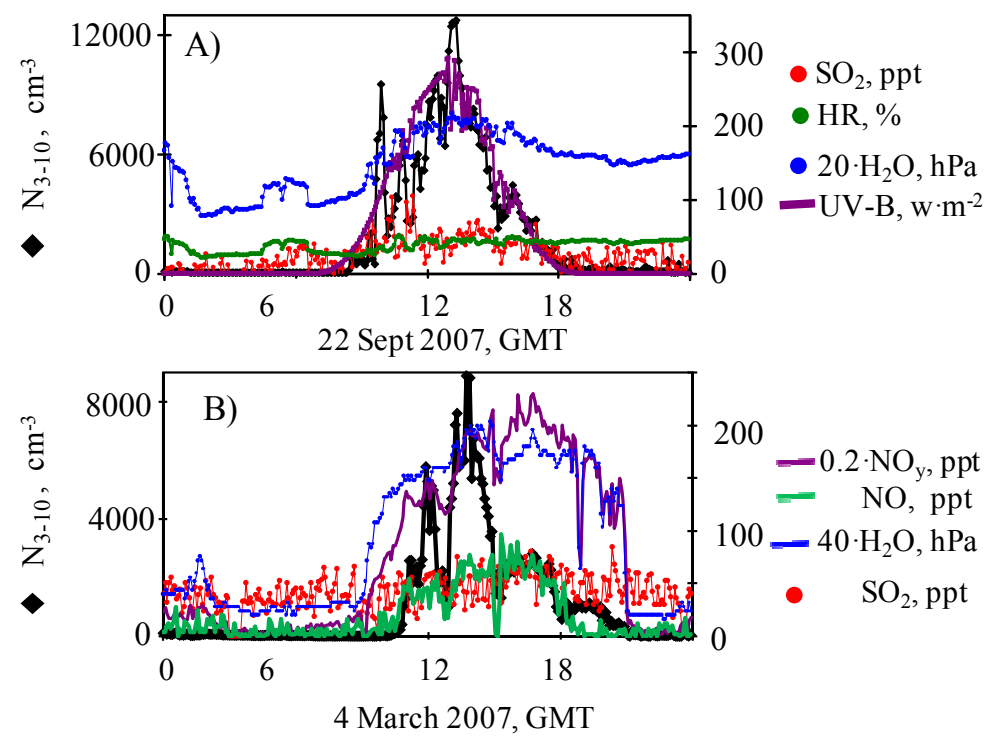

Fig. 10. 5-min averaged values of $\mathrm{N}_{3-10}, \mathrm{SO}_{2}$ and water vapour concentrations, relative humidity and UV-B radiation during two Type II events (22 September 2007 and 4 March 2007).

duration of $2 \mathrm{~h} 48 \mathrm{~min}$ ) were observed in the January to December 2007 period (264 days with available data). All analyses of the " $\mathrm{N}_{3-10}$ versus $\mathrm{SO}_{2}$ " slope shown below are based on slopes obtained from fittings with an $r^{2}$ coefficient $>0.7$. In all cases $\mathrm{SO}_{2}$ concentrations were above detection limit (60 ppt).

- Type II. During these episodes $\mathrm{N}_{3-10}$ concentrations were higher than $500 \mathrm{~cm}^{-3}$ and correlations between $\mathrm{N}_{3-10}$ and $\mathrm{SO}_{2}$ were not observed. Most of these episodes occurred from 12:00 to 16:00 GMT (later than Type I events; Table 3), when $\mathrm{N}_{3-10}$ concentrations experienced significant increases not observed in $\mathrm{SO}_{2}$ levels. In most of these events, increases in $\mathrm{NO}_{\mathrm{y}}$ concentrations were observed. Figure 10 shows some of these episodes occurred on 22 September, 2007 during the whole daylight period (Fig. 10a) and 4 March, 2007 during the central part of daylight (Fig. 10b). A total of 87 events (with an average duration of $3 \mathrm{~h} 36 \mathrm{~min}$ ) were observed in the January to December 2007 period (264 days with available data). During the $60 \%$ of these events, $\mathrm{SO}_{2}$ concentrations were above detection limit.

- Type III. In these episodes no significant night-todaylight increases in $\mathrm{N}_{3-10}$ were registered. Examples are not shown for the sake of brevity.

The fact that the relationship between $\mathrm{N}_{3-10}$ and $\mathrm{SO}_{2}$ is linear events Type I, suggests that the $\mathrm{N}_{3-10}$ and $\mathrm{SO}_{2}$ correlation is caused by cluster/particle growth to $\geq 3 \mathrm{~nm}$ size due to sulphuric acid condensation, even if $\mathrm{SO}_{2}$ concentrations are low (tens to hundreds of ppt). Fiedler et al. (2005) observed linear relationships between $\mathrm{H}_{2} \mathrm{SO}_{4}$ and the number of particles $>3 \mathrm{~nm}$, and it has been proposed that this behaviour is accounted for by the cluster activation theory (Kulmala et al., 2006).

During Type II events, no correlation between $\mathrm{N}_{3-10}$ and $\mathrm{SO}_{2}$ was observed. These events mostly occurred from 12:00 to 16:00 GMT, when solar radiation intensity is high and significant correlations between $\mathrm{N}_{3-10}$ and solar radiation were frequently observed (e.g. PC-1 in July 2007 in Table 2; Figs. 10a, 11a and b). This suggests that condensation of vapours brought about by photochemistry (not measured) plays a significant role in $3-10 \mathrm{~nm}$ particle formation. Two types of vapour may be involved: sulphuric acid and organic compounds. The fact that no correlation is observed between $\mathrm{SO}_{2}$ and $\mathrm{N}_{3-10}$ does not rule out that sulphuric acid condensation may contribute to $\mathrm{N}_{3-10}$ in these events. In fact, Weber et al. (1997) observed $\mathrm{H}_{2} \mathrm{SO}_{4}$ formation during daylight correlated with 3-4 nm particles, with no association with $\mathrm{SO}_{2}$ variations. Although this may occur, the contribution of organic vapours (not measured in this study) of natural or anthropogenic origin to $\mathrm{N}_{3-10}$ should be considered (Marti et al., 1996; Allan et al., 2006; Laaksonen et al., 2008). At Izaña, Fischer et al. (1998) observed that the concentrations of anthropogenic and biogenic (e.g. isoprene) organic compounds exhibited daily cycles similar to those we observed in $\mathrm{N}_{3-10}, \mathrm{SO}_{2}$, $\mathrm{NO}$ and $\mathrm{NO}_{\mathrm{y}}$. This indicates that natural biogenic and anthropogenic substances are mixed in the upward flows that reach Izaña. The mixing is caused by biogenic (e.g. forests of pines and other species around the island) and soil (e.g. NO) emissions during the upward flow regime that results in the transport of pollutants (e.g. $\mathrm{SO}_{2}$ and a fraction of $\mathrm{NO}$ and $\mathrm{NO}_{\mathrm{y}}$ ). In this air mass, organic compounds 
may contribute to $\mathrm{N}_{3-10}$ by "nucleation and condensation of pure organic substance" or by "condensation of organic compounds onto sulphuric acid containing droplets or clusters". The fact that the association between $\mathrm{N}_{3-10}$ and $\mathrm{SO}_{2}$ was observed in all PCA performed in this study suggests that this latter scenario is plausible.

Finally, it is important to highlight that although increases in $\mathrm{NO}$ and $\mathrm{NO}_{\mathrm{y}}$ concentrations are observed during Type II events, the oxidation product of these gases (nitrate) may not account for the observed $3-10 \mathrm{~nm}$ particles in the Type II events. Nitrate is typically observed at particle diameters $\geq 50 \mathrm{~nm}$ (Tolocka et al., 2004). As far as we know, this compound has not been detected in the $3-10 \mathrm{~nm}$ size and none theory has been proposed for this.

In summary, Type I events are attributed to 3-10 nm particle formation during the upward transport of air mass with relatively high $\mathrm{SO}_{2}$ concentrations (plumes of hundreds of ppts). In contrast, Type II events seem to be associated with fresh $3-10 \mathrm{~nm}$ particles formed in-situ due to the condensation of vapours recently formed. In both types of event gaseous precursors are attributed to emissions on the island. Figure 11 shows examples of two days on which Type I and II events occurred on a single day. The strong decoupling between Type I and II events in these examples supports the idea that these are different in nature.

\subsection{Influence of environmental parameters}

In this section we analyse the environmental conditions favouring the formation of $3-10 \mathrm{~nm}$ particles. Part of this analysis is based on the results shown in Tables 3 and 4 and Figs. 12 and 13.

\subsection{1 $\mathrm{SO}_{2}$ and $\mathrm{NO}_{\mathrm{y}}$ concentrations}

As stated above, correlations between $\mathrm{SO}_{2}$ and $\mathrm{N}_{3-10}$ were only observed during Type I events. $\mathrm{SO}_{2}$ concentrations (Fig. 12b) were higher during Type I events (monthly averages 100-300 ppt) than during Types II (35-70 ppt) and III $(30-150 \mathrm{ppt})$ events. Concentrations of $\mathrm{NO}_{\mathrm{y}}$ (not shown in Fig. 12 for the sake of brevity) were almost the same during Types I (300-800 ppt) and II (430-900 ppt) events, and much lower during Type III episodes (250-500 ppt). The fact that $\mathrm{NO}_{\mathrm{y}}$ concentrations were relatively high during Type II events suggests that these air masses may bring organic compounds that may contribute to $\mathrm{N}_{3-10}$ with two possible origins (Marti et al., 1996): i) anthropogenic emissions at low altitude on the island ( $<600 \mathrm{~m}$ a.s.l., well below the stratocumulus layer) and subsequent upward transport, and ii) biogenic emission (in the forest between 600 and $2000 \mathrm{~m}$ a.s.1.) mixed with polluted air during upward transport.
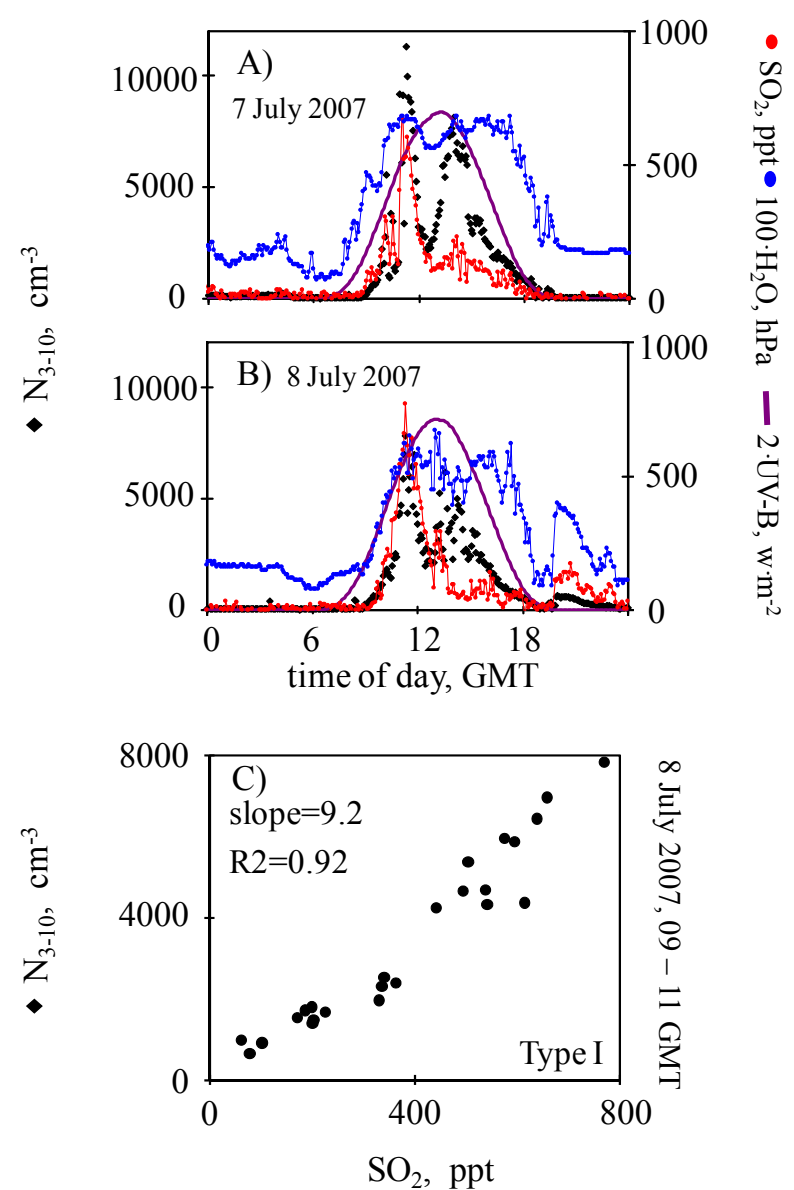

Fig. 11. 5-min average values of $\mathrm{N}_{3-10}, \mathrm{SO}_{2}$ and water vapour concentrations and UV-B radiation during two days on which Type I and Type II events were registered on a single day (7 and 8 July 2007). $\mathrm{N}_{3-10}$ versus $\mathrm{SO}_{2}$ concentrations during the Type I event recorded the 8 July 2007 from 09:30 to 11:30 GMT (C).

\subsubsection{Surface of pre-existing particles as a condensation sink}

The above described negative association of the particle mass $\mathrm{PM}_{10}$ concentration with PC-1 (Table 2) indicates that high surface area concentration $(\mathrm{S})$ of pre-existing $\mathrm{PM}_{10}$ particles hinders the formation of $3-10 \mathrm{~nm}$ particles. Observe that $S_{10}$ (surface area of particles less than $10 \mu \mathrm{m}$ ) is highly correlated with $\mathrm{PM}_{10}$ (Fig. 13a; owing to the fact that accumulation $0.1-1 \mu \mathrm{m}$ and coarse $1-10 \mu \mathrm{m}$ mode particles are the main contributors to both the particle mass and surface area), whereas $\mathrm{N}_{3-10}$ concentrations and the " $\mathrm{N}_{3-10}$ versus $\mathrm{SO}_{2}$ " slope are negatively correlated with $\mathrm{PM}_{10}$ (Fig. 14a and b).

The fact that NPF is observed on an almost day-to-day basis at Izaña (Fig. 5d) is, in part, aided by the low $\mathrm{S}$ concentrations typically registered in the upward flows where these $3-10 \mathrm{~nm}$ particles are formed. The $\mathrm{S}_{10}$ concentrations typically registered at Izaña (median $\sim 25 \mu \mathrm{m}^{2} \mathrm{~cm}^{-3}$; 
Table 4. Statistics of the hourly particle surface area (24 June 2008 to 1 October 2008) and particle PM 10 (17 November 2006 to 31 December 2007) concentrations recorded at Izaña.

\begin{tabular}{lrrrrr}
\hline $\mathrm{S}$ & $\begin{array}{r}0.014-0.1 \mu \mathrm{m} \\
\text { ultrafine }\end{array}$ & $\begin{array}{r}0.014-1 \mu \mathrm{m} \\
\text { fine }\end{array}$ & $\begin{array}{r}1-10 \mu \mathrm{m} \\
\text { coarse }\end{array}$ & $\begin{array}{r}0.014-10 \mu \mathrm{m} \\
\text { total }\end{array}$ & $\begin{array}{r}\mathrm{PM}_{10} \\
\mu \mathrm{g} / \mathrm{m}^{3}\end{array}$ \\
\hline mean & 4 & 20 & 25 & 45 & 13 \\
$\%$ & 8 & 44 & 56 & & \\
25 th & 2 & 10 & 0 & 11 & 0.4 \\
50 th & 2 & 18 & 7 & 28 & 1.3 \\
75 th & 4 & 27 & 43 & 71 & 7.9 \\
90 th & 8 & 36 & 72 & 103 & 40.2 \\
\hline
\end{tabular}

Table 4) are close to those observed in the mid and upper troposphere ( $\mathrm{S}_{10}: 2-20 \mu \mathrm{m}^{2} \mathrm{~cm}^{-3}$; Schröder et al., 2004) and much lower than those registered in the boundary layer (e.g., $\mathrm{S}_{1}$ (S for submicron particles) $\sim 450 \mu \mathrm{m}^{2} \mathrm{~cm}^{-3}$ in Northern Italy; Rodríguez et al., 2005). These low $\mathrm{S}$ concentrations (favouring nucleation in the upward flows) are facilitated by two main processes:

- the low background S concentration in the "free troposphere air mass" where the 'MBL air' enters (mixes with it) during the upward transport,

- cloud processing resulting in aerosol activation, cloud droplet formation and scavenging in the stratocumulus clouds during the upward transport of MBL air. This process typically results in the scavenging of particles $\geq 100 \mathrm{~nm}$ which are the most important contributors to the aerosol mass and surface area (Weber and McMurry, 1996; Henning et al., 2002). This "pre-existing particle" scavenging process in the upward flows (which is favoured by the fact that Izaña is regularly above cloud condensation level) accounts for two facts: i) the low $\mathrm{PM}_{10}$ concentrations (e.g. a median of $1.3 \mu \mathrm{g} \mathrm{m}^{-3}$ during 2007, Table 4) and low night-to-daylight increases in $\mathrm{PM}_{10}$ due to the upward flow regimen $\left(\sim 1 \mu \mathrm{g} \mathrm{m}^{-3}\right.$; Fig. 6b) at Izaña, and ii) sea salt particles are not detected in the aerosol chemical composition at Izaña, even if sea salt concentrations are high $\left(\sim 10 \mu \mathrm{g} \mathrm{m}^{-3}\right.$ in $\mathrm{PM}_{10}$ as an annual mean) in the marine boundary layer (Putaud et al., 2000; Alastuey et al., 2005). This in-cloud particle scavenging process was also observed in Mauna Loa and Puy de Dôme mounts (Weber and McMurry, 1996; Venzac et al., 2007). Moreover, this NPF link to low S concentrations in the outflows and/or surrounding area of clouds was also described by Kanawade and Tripathi (2006) and by Perry and Hobbs (1994) and Clarke et al. (1998) close to marine cumulus.
At Izaña, significant increases in the particle mass $\mathrm{PM}_{10}$ and $\mathrm{S}_{10}$ concentrations are registered during Saharan dust events (Chiapello et al., 1999; Maring et al., 2000; Alastuey et al., 2005), when hourly $\mathrm{PM}_{10}$ and $\mathrm{S}_{10}$ concentrations as high as $1000 \mu \mathrm{g} \mathrm{m}^{-3}$ and $200 \mu \mathrm{m}^{2} \mathrm{~cm}^{-3}$ have been recorded (e.g. summer 2008, Fig. 13a). These dust transport episodes typically occur in summer and sporadically in March (see monthly averaged $\mathrm{PM}_{10}$ levels in black dots in Fig. 12c). Observe in Fig. 13b and Table 4 that increases in S concentrations are mostly caused by an increase in surface area of coarse particles because of the coarse nature of the dust (coarse particles account for $>70 \%$ of $S_{10}$ during dust events when $\mathrm{S}_{10}$ is $>100 \mu \mathrm{m}^{2} \mathrm{~cm}^{-3}$ and for $<20 \%$ of $\mathrm{S}$ when $\mathrm{S}_{10}$ is $<20 \mu \mathrm{m} \mathrm{cm}^{-3}$; Table 4). These high $\mathrm{S}$ concentrations of coarse particles during Saharan episodes hinder nucleation and favour condensation of gaseous precursors onto pre-existing particles. Furthermore, the surface of mineral dust has a strong affinity to absorb $\mathrm{SO}_{2}$ and $\mathrm{H}_{2} \mathrm{SO}_{4}$ and consequently to decrease the concentrations of an important 3 $10 \mathrm{~nm}$ particle precursor (Dentener et al., 1996; Alastuey et al., 2005). These processes result in a decrease in the "NPF rates" in the presence of dust particles and account for the observed negative correlation between $\mathrm{PM}_{10}$ and $\mathrm{N}_{3-10}$ (Fig. 14a) and between $\mathrm{PM}_{10}$ and the " $\mathrm{N}_{3-10}$ versus $\mathrm{SO}_{2}$ " slope (Fig. 14b). Observe that high $\mathrm{PM}_{10}$ concentrations: i) resulted in Type III events (low $\mathrm{N}_{3-10}$ concentrations) in July 2007, even when $\mathrm{SO}_{2}$ levels during these episodes were high $(\sim 150$ ppt; Fig. 12a, b and c), and ii) in August 2007 resulted in a decrease in the "N $\mathrm{N}_{3-10}$ versus $\mathrm{SO}_{2}$ " slope and low $\mathrm{N}_{3-10}$ concentrations (Fig. 12a, $\mathrm{c}$ and d).

\subsubsection{Solar radiation}

Levels of G, DI, PAR and UV-B radiation did not show significant variations during the different types of event (e.g. UV-B in Fig. 12e). This is attributed to the fact that solar radiation intensity remains high above the stratocumulus layer (Fig. 3). In the "N $\mathrm{N}_{3-10}$ versus $\mathrm{SO}_{2}$.UV-B product" plot shown in Fig. 14c, two regions are well defined. In the region attributed to Type I events, a linear relationship between $\mathrm{N}_{3-10}$ and the $\mathrm{SO}_{2} \cdot \mathrm{UV}-\mathrm{B}$ product is observed. This 
agrees with the results obtained in model simulations by Pirjola (1999), who showed that an increase in UV-B radiation results in an enhancement of $\mathrm{SO}_{2}$ oxidation and new $\mathrm{H}_{2} \mathrm{SO}_{4}$ $\mathrm{H}_{2} \mathrm{O}$ particle production. These results suggest that radiation is not a limiting factor in activating $\mathrm{OH}$ production and the reactions resulting in the photo-oxidation of particle precursors in the free troposphere.

\subsubsection{Temperature}

Temperature had a clear influence on the NPF rates. Observe in Fig. 14b that high " $\mathrm{N}_{3-10}$ versus $\mathrm{SO}_{2}$ " slopes $\left(>20 \mathrm{~cm}^{-3} \mathrm{ppt}^{-1}\right.$; indicating high NPF rates) were only registered when the temperature was $\leq 15^{\circ} \mathrm{C}$, whereas low "N $\mathrm{N}_{3-10}$ versus $\mathrm{SO}_{2}$ " slopes $\left(<10 \mathrm{~cm}^{-3} \mathrm{ppt}^{-1}\right)$ were observed when the temperature was $>20^{\circ} \mathrm{C}$. These results fit with those found by Eastern and Peters (1994), who showed that the NPF rates due to binary $\mathrm{H}_{2} \mathrm{SO}_{4}-\mathrm{H}_{2} \mathrm{O}$ nucleation and condensational growth (which is considered an important NPF mechanism in the free troposphere; Kulmala and Kerminen, 2008) increased when temperature decreased. If it is assumed that stable clusters are always present in the atmosphere (as suggested by Kulmala and co-workers; Kulmala et al., 2005; Kulmala and Tammet, 2007), then the increase we observe in the " $\mathrm{N}_{3-10}$ versus $\mathrm{SO}_{2}$ " slope would indicate that clusters activation and growth is favoured by decreases in temperature.

The influence of temperature on NPF in upslope winds has also been observed in other mountaintop observatories. At Norikura mount, high NPF rates were observed when upslope winds mixed with northern cold air above (Nishita et al., 2008). In Jungfraujoch mount, nucleation particles reached a maximum in winter (Weingartner et al., 1999). Siebert et al. (2004) observed high concentrations of 5-10 nm particles close to an inversion layer, and they argued that the strong change in temperature and humidity experienced by the air mass when it crossed the inversion (due to upward thermal circulation) favoured NPF. This may occur in the inversion layer typically located below Izaña (just above the stratocumulus clouds).

\section{$4.5 \mathbf{N}_{3-10}$ concentrations and seasonal evolution}

$\mathrm{N}_{3-10}$ concentrations were significantly different during the different types of event. The monthly averaged values of $\mathrm{N}_{3-10}$ were within the range $1000-2500 \mathrm{~cm}^{-3}$ during Type I events, $2000-4000 \mathrm{~cm}^{-3}$ during Type II events and 400$600 \mathrm{~cm}^{-3}$ during Type III events (Fig. 12a). Several processes may account for the fact that $\mathrm{N}_{3-10}$ concentrations are higher during Type II events than during Type I events: i) $\mathrm{PM}_{10}$ and $\mathrm{S}_{10}$ concentrations were higher during Type $\mathrm{I}$ events (this favours condensation rather than nucleation in these events; Fig. 12c), ii) the temperature was higher during Type I events (this increases equilibrium vapour pressure and consequently hinders the gas to aerosol phase conver-
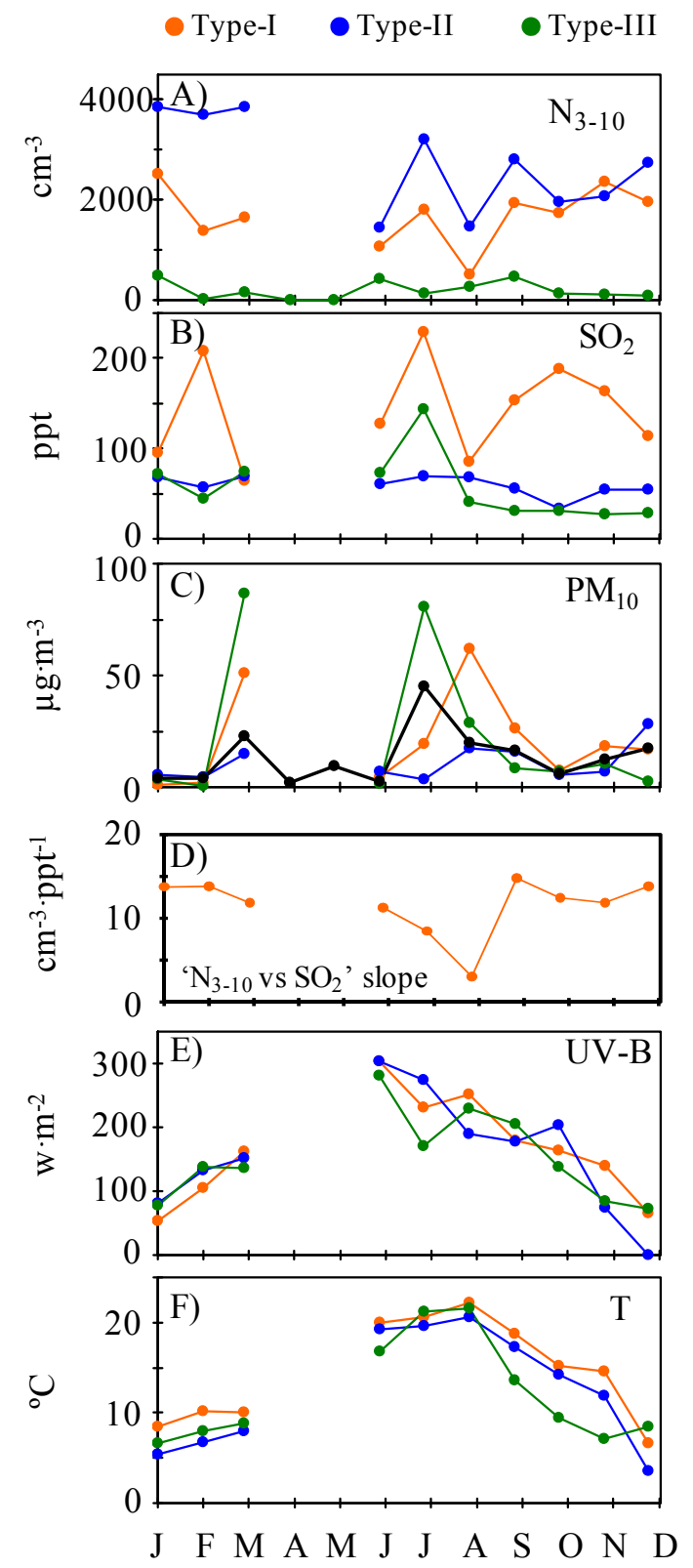

Fig. 12. Monthly averaged values of $\mathrm{N}_{3-10}, \mathrm{SO}_{2}, \mathrm{PM}_{10}$, the ' $\mathrm{N}_{3-10}$ versus $\mathrm{SO}_{2}$ " slope, UV-B radiation and temperature during the Type I, II and III events recorded during 2007. Black dot for $\mathrm{PM}_{10}$ (C) indicates monthly average calculated with all days/month.

sion; Fig. 12f), and iii) if Type I events are attributed to particle formation during upward transport and Type II attributed to in-situ formation, then coagulation processes during the transport may contribute to the drop in $\mathrm{N}_{3-10}$ concentrations. Type III events occurred under free troposphere (low $\mathrm{SO}_{2}$ and $\mathrm{NO}_{\mathrm{y}}$ concentrations; Fig. 12b) or Saharan dust (high $\mathrm{PM}_{10}$ and surface area concentrations favourable for condensation; Fig. 12c) conditions. 

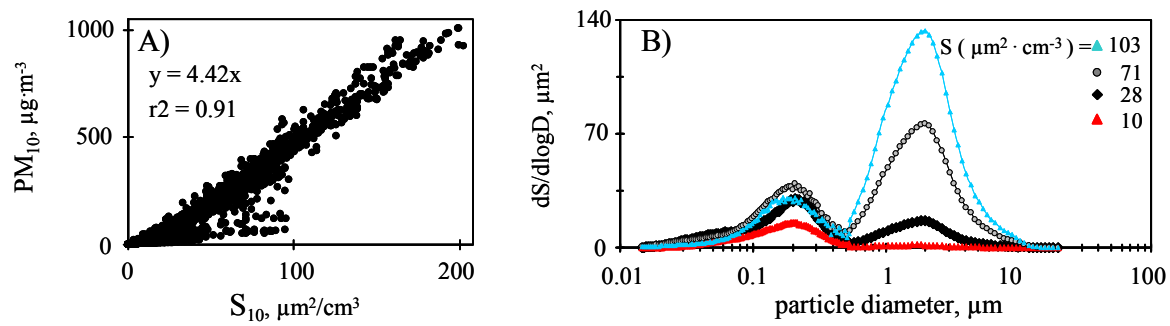

Fig. 13. (A) $\mathrm{PM}_{10}$ versus $\mathrm{S} 10$ concentrations, and (B) dS/dlogD particle surface area size distribution associated to $\mathrm{S}$ values corresponding to percentiles 90th $(103 \mathrm{~m} 2 \mathrm{Ecm}-3), 75$ th $(71 \mathrm{~m} 2 \mathrm{Ecm}-3), 50$ th $(28 \mathrm{~m} 2 \mathrm{Ecm}-3), 75$ th $(71 \mathrm{~m} 2 \mathrm{Ecm}-3), 50$ th $\left(23 \mu \mathrm{m}^{2} \mathrm{~cm}^{-3}\right)$ and 25 th $\left(10 \mu \mathrm{m}^{2} \mathrm{~cm}^{-3}\right)$. Data recorded at Izana from June to September 2007.
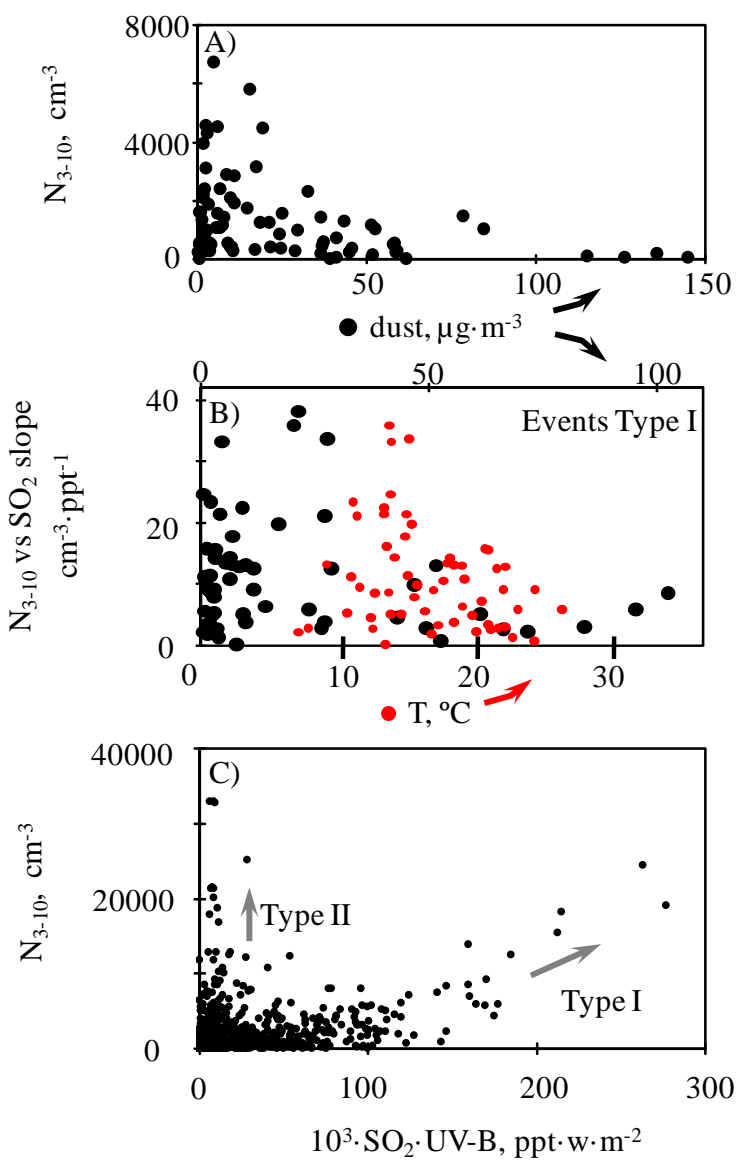

Fig. 14. (A) $\mathrm{N}_{3-10}$ versus PM10 concentrations (July to September 2007), (B) " $\mathrm{N}_{3-10}$ versus $\mathrm{SO}_{2}$ " slope (events with $r^{2}>0.7$ ) versus $\mathrm{PM}_{10}$ and temperature, $(\mathrm{C}) \mathrm{N}_{3}-10$ versus the $\mathrm{SO}_{2} \cdot \mathrm{UV}-\mathrm{B}$ product.

Conditions for reaching high rates of 3-10 nm particle formation were more favourable in winter than in summer. The slightly higher values of the hourly " 15 th, 25 th and 50th percentiles of $\mathrm{N}_{3-10}$ " and the "averaged values of $\mathrm{N}_{3-10}$ " (Fig. 5d and f) recorded in the summer were caused by the lower frequency of Type III events (6-10 events/month in summer and 11-17 events/month in the other seasons; Table 3). In contrast, the "95th and 90th percentiles of $\mathrm{N}_{3-10}$ " reached higher values in autumn and winter $\left(10000-20000 \mathrm{~cm}^{-3}\right)$ than in summer $\left(5000 \mathrm{~cm}^{-3}\right.$; Fig. 5e). This higher efficiency in the NPF mechanisms in winter is favoured by the lower temperature and the lower surface area of pre-existing $\mathrm{PM}_{10}$ particles (Fig. 12c). Observe that the monthly means of the " $\mathrm{N}_{3-10}$ versus $\mathrm{SO}_{2}$ " slope were lower in summer $\left(2-8 \mathrm{~cm}^{-3} \mathrm{ppt}^{-1}\right)$ than in autumn and winter $\left(\sim 15 \mathrm{~cm}^{-3}\right.$ ppt $^{-1}$; Fig. 12d).

\section{Summary and conclusions}

A data set of aerosol size distribution, trace gases, a set of radiation components and meteorological data collected during 2007-2008 at Izaña Mountain observatory has been analysed with the aim of identifying the processes and conditions favouring the formation of $3-10 \mathrm{~nm}$ particles. This site is located at $2367 \mathrm{~m}$ a.s.l. on the island of Tenerife, well above the stratocumulus layer typical of the subtropical oceanic tropospheres. The development of orographic thermal-buoyant upward flows during daylight result in the upward transport of water vapour and trace gases emitted at low altitudes on the island by biogenic and anthropogenic sources. These airflows perturb the low free troposphere and result in high concentrations of 3-10 nm particles $\left(\mathrm{N}_{3-10}>10000 \mathrm{~cm}^{-3}\right.$ have been recorded several times) due to new particle formation (NPF). Two types of $\mathrm{N}_{3-10}$ event were observed. In Type I events, a linear relationship between $\mathrm{N}_{3-10}$ and $\mathrm{SO}_{2}$ was observed $\left(r^{2}\right.$ coefficients $0.70-0.95$, a mean slope of $11 \mathrm{~cm}^{-3} \mathrm{ppt}^{-1}$ and $\mathrm{SO}_{2}$ concentrations within the range from tens to hundreds of ppt). These particles seem to be formed during the upward transport process, most probably within or after the outflows of the cloud layer (marine cumulus slightly perturbed by the topography of the island) typically located well below Izaña. During Type II events 3-10 nm particles are formed in-situ around noon and during the afternoon probably due to condensation of vapours linked to photochemistry. In both types of event, the low surface area (S) of pre-existing particles favoured NPF in the upward flows. Such low S concentrations are favoured by the scavenging 
of pre-existing particles in the stratocumulus layer typically located below Izaña. Variations in temperature and in concentration of pre-existing particles influenced 3-10 nm particle formation. Because of the lower temperature and lower surface area of pre-existing particles, $\mathrm{N}_{3-10}$ concentrations were higher in Type II events than in Type I (even if $\mathrm{SO}_{2}$ concentrations were higher in Type I events). Moreover, NPF efficiency was greater in winter owing to the higher temperature and the presence of coarse (Saharan) dust particles in summer. This resulted in higher " $\mathrm{N}_{3-10}$ versus $\mathrm{SO}_{2}$ " slopes in autumn-winter (up to $40 \mathrm{~cm}^{-3} \mathrm{ppt}^{-1}$ in some events) than in summer (down to $2 \mathrm{~cm}^{-3} \mathrm{ppt}^{-1}$ in some events). Our observations show that NPF is favoured in the boundary layer to the free troposphere transition region by the low surface area of pre-existing particles (prompted by in-cloud particle scavenging), the gaseous precursor transport during the upward flow regime and the high solar radiation conditions above the marine cloud layer. The overall data analysis suggest that, although sulphuric acid participates in $3-10 \mathrm{~nm}$ particle formation, other vapours are likely involved in the particle formation during at least in one of the two type of events segregated.

The few worldwide aerosol observations at elevated mounts reaching the low free troposphere, suggest that NPF is favoured in the boundary layer to free troposphere transition region. The influence of the environmental conditions on the nanoparticles formation we have observed in the upslope winds at Izaña, were also observed at other high mountain observatories, such as Jungfraujoch (3580 m a.s.l., Switzerland), Mauna Loa (3400 m a.s.1., Hawaii), Khumbu (5079 m a.s.1., Nepal), Puy de Dôme (1465 m a.s.l.; France), Norikura (2770 m a.s.l.; Japan) and Lemmon (2790 m a.s.l., USA; Weber et al., 1996; Weber and McMurry, 1996; Weingartner et al., 1999; Shaw et al., 2007; Nishita et al., 2008; Venzac et al., 2008, 2009). These field observations suggest that elevated mounts reaching the low free troposphere may act as sources regions for new particles.

Acknowledgements. This study has been performed with financial support and within the framework of the project GRACCIE (CSD2007-00067). We thank Jose-Manuel Rodríguez-Sánchez (Ppsoft) for his support in picture production. The excellent work performed by Carlos Torres, Virgilio Carreño, Cándida Hernández and Julián Peréz in the everyday instrument checking is gratefully recognized.

Edited by: W. Birmili

\section{References}

Alastuey, A., Querol, X., Castillo, S., Escudero, M., Avila, A., Cuevas, E., Torres, C., Romero, P. M., Exposito, F., García, O., Díaz, J. P., Van Dingenen, R., and Putaud, J. P.: Characterisation of TSP and PM2.5 at Izaña and Santa Cruz de Tenerife (Canary Islands, Spain) during a Saharan Dust Episode (July 2002), Atmos. Environ., 39, 4715-4728, 2005.
Allan, J. D., Alfarra, M. R., Bower, K. N., Coe, H., Jayne, J. T., Worsnop, D. R., Aalto, P. P., Kulmala, M., Hyötyläinen, T., Cavalli, F., and Laaksonen, A.: Size and composition measurements of background aerosol and new particle growth in a Finnish forest during QUEST 2 using an Aerodyne Aerosol Mass Spectrometer, Atmos. Chem. Phys., 6, 315-327, 2006, http://www.atmos-chem-phys.net/6/315/2006/.

Benson, D. R., Li-Hao Young, , Shan-Hu Lee, , Campos, T. L., Rogers, D. C., and Jensen, J.: The effects of airmass history on new particle formation in the free troposphere: case studies, Atmos. Chem. Phys., 8, 3015-3024, 2008, http://www.atmos-chem-phys.net/8/3015/2008/.

Chiapello, I., Prospero, J. M., Herman, J. R., and Hsu, N. C.: Detection of mineral dust over the North Atlantic Ocean and Africa with Nimbus 7 TOMS, J. Geophys. Res., 104, 9277-9291, 1999.

Clarke, A. D., Varner, J. L., Eisele, F., Maudin, R. L., Tarnner, D., and Litchy, M.: Particle production in the remote marine Atmosphere: cloud outflow and subsidence during ACE-1, J. Geophys. Res., 103, 16396-16409, 1998.

Dentener, F., Carmichael, G. R., Zhang, Y., Lelieveld, J., and Crutzen, P. J.: Role of mineral dust as a reactive surface in the global Atmosphere, J. Geophys. Res., 101, 22869-22889, 1996.

Fischer, H., Nikitas, C., Parchatka, U., Zenker, T., Harris, G. W., Matuska, P., Schmitt, R., Mihelcic, D., Muesgen, P., H. W., Paetz, Schultz, M., and Volz-Thomas, A.: Trace gas measurements during the oxidizing capacity of the troposphere campaign 1993 at Izaña, J. Geophys. Res., 103, 13505-13518, 1998.

Font, I.: El tiempo Atmosférico en las islas Canarias, Servicio Nacional de Meteorología, 96 pp., 1956.

Easter, R. C. and Peters, L. K.: Binary homogeneous nucleation: temperature and relative humidity fluctuations, nonlinearity and aspects of new particle production in the Atmosphere, J. Appl. Meteorol., 33, 775-784, 1994.

Eisele, F. L. and McMurry, P. H.: Recent Progress in Understanding Particle Nucleation and Growth, Philos, T. Roy. Soc. London B., 352(1350), 191-200, 1997.

Fiedler, V., Dal Maso, M., Boy, M., Aufmhoff, H., Hoffmann, J., Schuck, T., Birmili, W., Hanke, M., Uecker, J., Arnold, F., and Kulmala, M.: The contribution of sulphuric acid to atmospheric particle formation and growth: a comparison between boundary layers in Northern and Central Europe, Atmos. Chem. Phys., 5, 1773-1785, 2005, http://www.atmos-chem-phys.net/5/1773/2005/.

Hermann, M., Heintzenberg, J., Wiedensohler, A., Zahn, A., Heinrich, G., and Brenninkmeijer, C. A. M.: Meridional distributions of aerosol particle number concentrations in the upper troposphere and lower stratosphere obtained by Civil Aircraft for Regular Investigation of the Atmosphere Based on an Instrument Container (CARIBIC) flights, J. Geophys. Res., 108, 4114, doi:10.1029/2001JD001077, 2003.

Hegg, D. A., Radke, L. F., and Hobbs, P. V.: Measurements of aitken nuclei and cloud condensation nuclei in the marine Atmosphere and their relation to the DMS- cloud-climate hypothesis, J. Geophys. Res., 96, 18727-18733, 1991.

Henning, S., Weingartner, E., Schmidt, S., Wendisch, M., Gäggeler, H. W., and Baltenspenger, U.: Size-dependent aerosol activation at the high-alpine site Jungfraujoch (3580 m a.s.1.), Tellus, 54B, 82-95, 2002.

Kanawade, V. and Tripathi, S. N.: Evidence for the role of 
ion-induced particle formation during an Atmospheric nucleation event observed in Tropospheric Ozone Production about the Spring Equinox (TOPSE), J. Geophys. Res., 111, D02209, doi:10.1029/2005JD006366, 2006.

Kesik, M., Ambus, P., Baritz, R., Brüggemann, N., ButterbachBahl, K., Damm, M., Duyzer, J., Horváth, L., Kiese, R., Kitzler, B., Leip, A., Li, C., Pihlatie, M., Pilegaard, K., Seufert, S., Simpson, D., Skiba, U., Smiatek, G., Vesala, T., and ZechmeisterBoltenstern, S.: Inventories of $\mathrm{N} 2 \mathrm{O}$ and $\mathrm{NO}$ emissions from $\mathrm{Eu}-$ ropean forest soils, Biogeosciences, 2, 353-375, 2005, http://www.biogeosciences.net/2/353/2005/.

Kim, C. S., Adachi, M., Okuyama, K., and Seinfeld, J. H.: Effect of $\mathrm{NO}_{2}$ on Particle Formation in $\mathrm{SO}_{2} / \mathrm{H}_{2} \mathrm{O}$ /air Mixtures by IonInduced and Homogenous Nucleation, Aerosol Sci. Tech., 36, 941-952, 2002.

Kleiss, J., Honrath, R. E., Dziobak, M. P., Tanner, D., Val Martín, M., Owen, R. C., and Helmig, D.: Occurrence of upslope flows at the Pico mountaintop observatory: A case study of orographic flows on a small, volcanic island, J. Geophys. Res., 112, D10S35, doi:10.1029/2006JD007565, 2007.

Kulmala, M., Pirjola, L., and Mäkela, J. M.: Stable sulphate clusters as a source of new Atmospheric particles, Nature, 404, 66-69, 2000.

Kulmala, M., Laakso, L., Lehtinen, K. E. J., Riipinen, I., Dal Maso, M., Anttila, T., Kerminen, V.-M., Hõrrak, U., Vana, M., and Tammet, H.: Initial steps of aerosol growth, Atmos. Chem. Phys., 4, 2553-2560, 2004, http://www.atmos-chem-phys.net/4/2553/2004/.

Kulmala, M., Lehtinen, K. E. J., Laakso, L., Mordas, G., and Hämeri, K.: On the existence of neutral atmospheric clusters, Boreal Environ. Res., 10, 79-87, 2005.

Kulmala, M., Lehtinen, K. E. J., and Laaksonen, A.: Cluster activation theory as an explanation of the linear dependence between formation rate of $3 \mathrm{~nm}$ particles and sulphuric acid concentration, Atmos. Chem. Phys., 6, 787-793, 2006, http://www.atmos-chem-phys.net/6/787/2006/.

Kulmala, M., Tammet, H.: Finnish-Estonian air ion and aerosol workshops. Boreal Environ. Res., 12, 237-245, 2007

Kulmala, M. and Kerminen, V. M.: On the formation and growth of Atmospheric nanoparticles, Atmos. Res., 90, 132-150, 2008.

Laaksonen, A., Kulmala, M., O’Dowd, C. D., Joutsensaari, J., Vaattovaara, P., Mikkonen, S., Lehtinen, K. E. J., Sogacheva, L., Dal Maso, M., Aalto, P., Petäjä, T., Sogachev, A., Yoon, Y. J., Lihavainen, H., Nilsson, D., Facchini, M. C., Cavalli, F., Fuzzi, S., Hoffmann, T., Arnold, F., Hanke, M., Sellegri, K., Umann, B., Junkermann, W., Coe, H., Allan, J. D., Alfarra, M. R., Worsnop, D. R., Riekkola, M. -L., Hyötyläinen, T., and Viisanen, Y.: The role of VOC oxidation products in continental new particle formation, Atmos. Chem. Phys., 8, 2657-2665, 2008, http://www.atmos-chem-phys.net/8/2657/2008/.

Lee, S.-H., Wilson, J. C., Baumgardner, D., Herman, R. L., Weinstock, E. M., LaFleur, B. G., Kok, G., Anderson, B., Lawson, P., Baker, B., Strawa, A., Pittman, J. V., Reeves, J. M., and Bui, T. P.: NPF observed in the tropical/subtropical cirrus clouds, J. Geophys. Res., 109, D02009, doi:10.1029/2004JD005033, 2004.

Maring, H., Savoie, D. L., Izaguirre, M. A., McCormick, C., Arimoto, R., Prospero, J. M., and Pilinis, C.: Aerosol Phys.ical and optical properties and their relationship to aerosol composition in the free troposphere at Izaña, Tenerife, Canary Islands, during
July 1995, J. Geophys. Res., 105, 14677-14700, 2000.

Marti, J. J, Weber, R. J., McMurry, P. H., Eisele, F., Tanner, D., and Jefferson, A.: New particle formation at a remote continental site: Assessing the contributions of $\mathrm{SO}_{2}$ and organic precursors, J. Geophys. Res., 102, 6331-6339, 1997.

Nishita, C., Osada, K., Kido, M., Matsunaga, K., and Iwasaka, Y.: Nucleation mode particles in upslope valley winds at Mount Norikura, Japan: Implications for the vertical extent of new particle formation events in the lower troposphere, J. Geophys. Res., 113, D06202, doi:10.1029/2007JD009302, 2008.

O’Dowd, C. D., Aalto, P., Hmeri, K., Kulmala, M., and Hoffmann, T.: Aerosol Formation: Atmospheric Particles from Organic Vapours, Nature, 416, 497-498, 2002.

Perry, K. D. and Hobbs, P. V.: Further evidence for particle nucleation in clean air adjacent to marine cumulus clouds, J. Geophys. Res., 99, 22803-22818, 1994.

Pirjola, L.: Effects of the increased UV radiation and biogenic VOC emissions on the ultrafine sulphate aerosol formation, J. Aerosol Sci., 30, 355-367, 1999.

Putaud, J. P., Van Dingenen, R., Mangoni, M., Virkkula, A., Raes, F., Maring, H., Prospero, J. M., Swietlicki, E., Berg, O. H., Hillamo, R., and Mäkela, T.: Chemical mass closure and assessment of the origin of the submicron aerosol in the marine boundary layer and the free troposphere at Tenerife during ACE2, Tellus, 52B, 141-168, 2000.

Raes, F., Van Dingenen, R., Cuevas, E., Van Velthoven, F. J. V., and Prospero, J. M.: Observations of aerosols in the free troposphere and marine boundary layer of the subtropical Northeast Atlantic: discussion of processes determining their size distribution, J. Geophys. Res., 102, 21315-21328, 1997.

Rodríguez, S., Van Dingenen, R., Putaud, J. P., Martins-Dos Santos, S., and Roselli, D.: Nucleation and growth of new particles in the rural Atmosphere of Northern Italy - Relationship to air quality monitoring, Atmos. Environ., 39, 6734-6746, 2005.

Schröder, F. P., Kärcher, B., Fiebig, M., and Petzold, A.: Aerosol states in the free troposphere at northern midlatitudes, J. Geophys. Res., 107(D21), 8126, doi:10.1029/2000JD000194, 2002.

Shaw, G. E.: Aerosols at a mountaintop observatory in Arizona, J. Geophys. Res., 112, D07206, doi:10.1029/2005JD006893, 2007.

Tolocka, M. P., Lake, D. A., Johnston, M. V., and Wexler, A. S.: Ultrafine nitrate particle events in Baltimore observed by real-time single particle mass spectrometry, Atmos. Environ., 38, 32153223, 2004.

Venzac, H., Sellegri, K., and Laj, P.: Nucleation events detected at the high altitude site of the Puy de Dôme Research station, France, Boreal Environ. Res., 12, 345-359, 2007.

Venzac, H., Sellegri, K., Laj, P., Villani, P., Bonasoni, P., Marinoni, A., Cristofanelli, P., Calzolari, F., Fuzzi, S., Decesari, S., Facchini, M. C., Vuillermoz, E., and Verza, G. P.: High frequency new particle formation in the Himalayas. P. Natl. Acad. Sci. USA, 105(41), 15666-15671, 2008.

Venzac, H., Sellegri, K., Villani, P., Picard, D., and Laj, P.: Seasonal variation of aerosol size distributions in the free troposphere and residual layer at the puy de Dme station, France, Atmos. Chem. Phys., 9, 1465-1478, 2009,

http://www.atmos-chem-phys.net/9/1465/2009/.

Van Dingenen, R., Putaud, J.-P., Martins-Dos Santos, S., and Raes, F.: Physical aerosol properties and their relation to air mass origin at Monte Cimone (Italy) during the first MINATROC cam- 
paign, Atmos. Chem. Phys., 5, 2203-2226, 2005, http://www.atmos-chem-phys.net/5/2203/2005/.

Wiedensohler, A., Hansson, H. C. ,Orsini, D. , Wendisch, M., Wagner, F., Bower, K. N., Choularton, T. W., Wells,M., Parkin, M., Acker, A., Wieprecht, W., Fachini, M. C.,Lind, J. A., Fuzzi, S.,Arends, B. G., and Kulmala, M.: Nighttime formation and occurrence of new particles associated with orographic clouds, Atmos. Environ., 31, 2545-2559, 1997.

Weber, R. J. and McMurry, P. H.: Fine particle size distribution at the Mauna Loa Observatory, Hawaii, J. Geophys. Res., 101, 14767-14775, 1996.
Weber, R. J., Marti, J. J., McMurry, P. H., Eisele, F. L., Tanner, D. J., and Jefferson, A.: Measurements of new particle formation and ultra fine particle growth at a clean continental site, J. Geophys. Res., 102, 4375-4385, 1997.

Weingartner, E., Nyeki, S., and Baltensperger, U.: Seasonal and diurnal variation of aerosol size distributions $(10<\mathrm{D}<750 \mathrm{~nm})$ at a high-alpine site (Jungfraujoch $3580 \mathrm{~m}$ a.s.1.), J. Geophys. Res., 104(D21), 26809-26820, 1999. 